\title{
10. MICROFACIES OF SOME SEDIMENTS FROM THE WESTERN NORTH ATLANTIC: PALEOCEANOGRAPHIC IMPLICATIONS (LEG 44 DSDP) ${ }^{1}$
}

\author{
Léo Pastouret and Gérard-André Auffret, Centre Océanologique de Bretagne, Brest, France \\ and \\ Hervé Chamley, Laboratoire de Géologie Marine, Centre Universitaire de Luminy, Marseille, France
}

\begin{abstract}
We characterized the microfacies of sediments encountered during Leg 44 on the basis of coarse fraction mineralogy $(\phi>125 \mu \mathrm{m})$, silt mineralogy $(63>\phi>20 \mu \mathrm{m})$, clay mineralogy $(\phi<2 \mu \mathrm{m})$, silt and clay particle size distributions, and calcium carbonate contents. Secondly we attempted to tentatively correlate microfacies changes with major oceanographic events which have affected the sedimentary processes along the continental margin of North America. Because part of the stratigraphic column was not recovered (no Pliocene and Oligocene, and reduced Pleistocene and Barremian sections), and because of the fairly large sampling intervals our results are far from complete and exhaustive. Some important results, however, concerning the evolution of the oceans since Barremian time were obtained.

From Albian to Upper Cretaceous the deep part of the Blake-Bahama Basin has been the site of deposition of sediments bearing organic matter (black shale facies). The particle-size distributions in these sediments suggest that circulation was weak and sediments were deposited from low density turbidity currents during that time. This supports the view that the organic matter had a continental origin.

On the Blake Plateau, in the vicinity of the Blake Escarpment, bathyal nannofossil and foraminifer ooze were deposited from Barremian to middle Eocene time. They overlie Lower Cretaceous reefal limestone. Two major hiatuses are present; the first one (representing approximately 30 million years) is between Albian and upper Campanian sediments; the second one (representing approximately 7 million years) is between Maestrichtian and Paleocene. The Blake Plateau appears to have been subjected to relatively weak currents before Albian and after Maestrichtian times. However, the 30 -million year hiatus detected on the edge of the Blake Nose could well be a result of intensification of the oceanic circulation. The second hiatus in the same area could also have resulted from a similar process. The particle-size distributions in Paleocene to middle Eocene silica-rich sediments, which contain large amounts of smectite, suggest that they were deposited by an active current system. This active circulation could be correlated with the initiation of Arctic Bottom Water and Antarctic Bottom Water systems. Sediments have not been deposited on the Blake Plateau since middle Eocene time and veneers of manganese nodules reflect the intensity of bottom circulation.

Contour and turbidity currents influenced deposition during the Pleistocene in the Blake-Bahama Basin. No Neogene sediments have been recovered from this area, although conditions similar to those that characterized the Pleistocene probably prevailed during that time.
\end{abstract}

\section{INTRODUCTION}

During Leg 44 of the D/V Glomar Challenger in the western part of the North Atlantic, holes were drilled at five sites in three areas: (1) Site 388 on the continental rise hills of North America; (2) Sites 389, 390, and 392 on the Blake Nose, a physiographic feature of the Blake Plateau; (3) Site

${ }^{1}$ Contribution 537 of the Départment Scientifique, Centre Océanologique de Bretagne.
391 in the Blake-Bahama Basin close to the Blake Escarpment. (Site data are given in Table 1.)

TABLE 1

Site Location

\begin{tabular}{lcccrc}
\hline Site & Latitude & Longitude & $\begin{array}{c}\text { Water } \\
\text { Depth } \\
(\mathrm{m})\end{array}$ & $\begin{array}{c}\text { Penetra- } \\
\text { tion } \\
(\mathrm{m})\end{array}$ & $\begin{array}{c}\text { Number } \\
\text { of Holes }\end{array}$ \\
\hline 388 & $35^{\circ} 31.33^{\prime} \mathrm{N}$ & $69^{\circ} 23.76^{\prime} \mathrm{W}$ & 4919 & 341 & 2 \\
389 & $30^{\circ} 08.54^{\prime} \mathrm{N}$ & $76^{\circ} 05.57^{\prime} \mathrm{W}$ & 2724 & 40 & 1 \\
390 & $30^{\circ} 08.54^{\prime} \mathrm{N}$ & $76^{\circ} 06.74^{\prime} \mathrm{W}$ & 2670 & 206 & 2 \\
391 & $28^{\circ} 13.61^{\prime} \mathrm{N}$ & $75^{\circ} 37.00^{\prime} \mathrm{W}$ & 4963 & 1412 & 4 \\
392 & $29^{\circ} 54.63^{\prime} \mathrm{N}$ & $76^{\circ} 10.68^{\prime} \mathrm{W}$ & 2607 & 349 & 2 \\
\hline
\end{tabular}


The sediments recovered from these five sites range from Upper Jurassic (Tithonian or Kimmeridgian) to Pleistocene. Most of them, and particularly those from the Blake Nose, consist of soft nannofossil ooze; however, silty clay, claystone, limestone, carbonaceous mud and mudstone were also recovered. Figure 1 shows location, stratigraphic columns, and tracings of seismic units at the sites drilled.
The main objective of this paper is to correlate lithologic variations with oceanographic events related to the geological evolution of the Atlantic Ocean.

\section{METHODS}

The sediment was subjected to: (1) coarse fraction analysis (grain size $>125 \mu \mathrm{m}$ ), (2) analysis of $\mathrm{CaCO}_{3}$ content in the

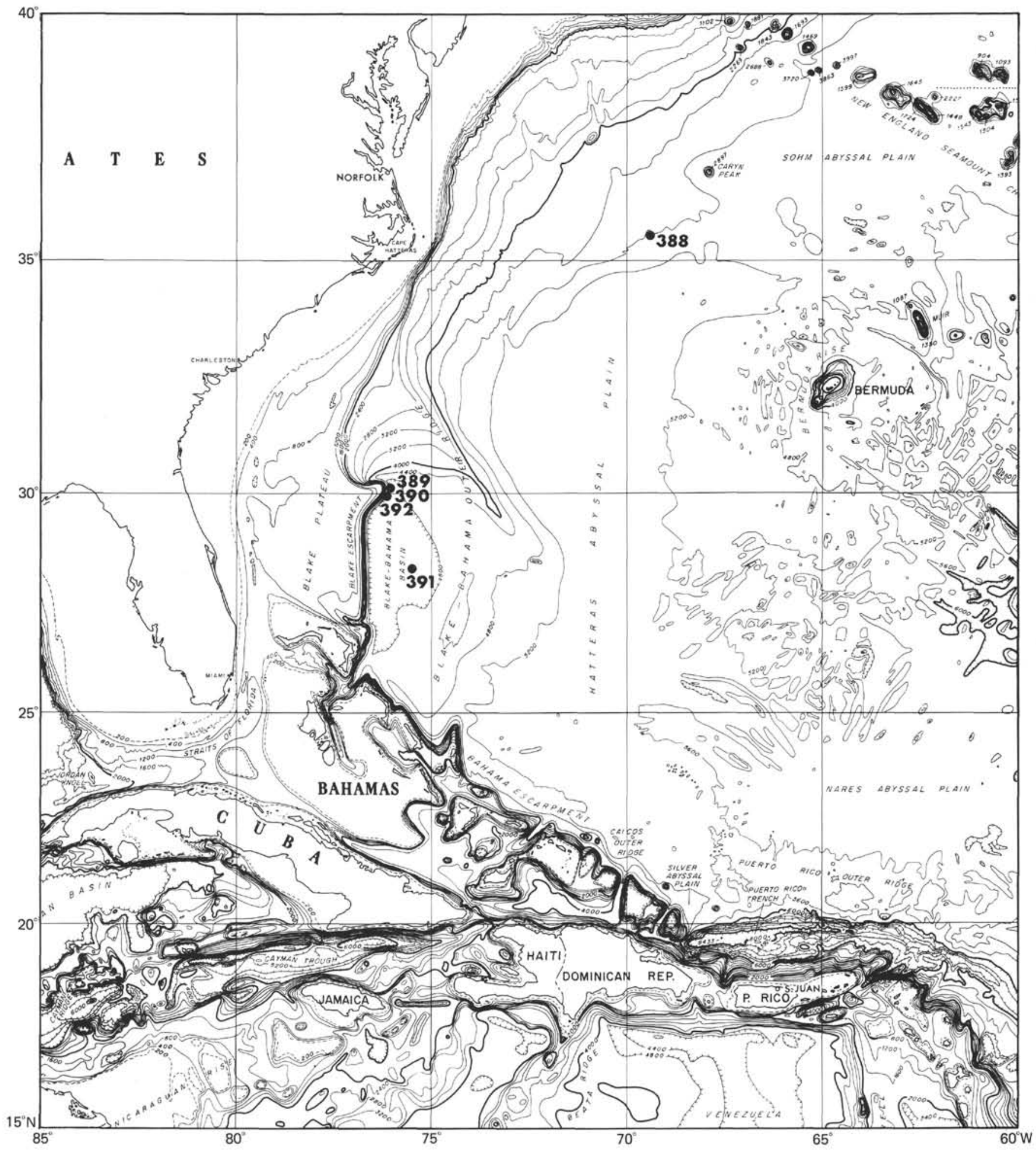

Figure 1. Location of holes drilled during Leg 44, tracings of seismic reflectors, and stratigraphy of sites. 

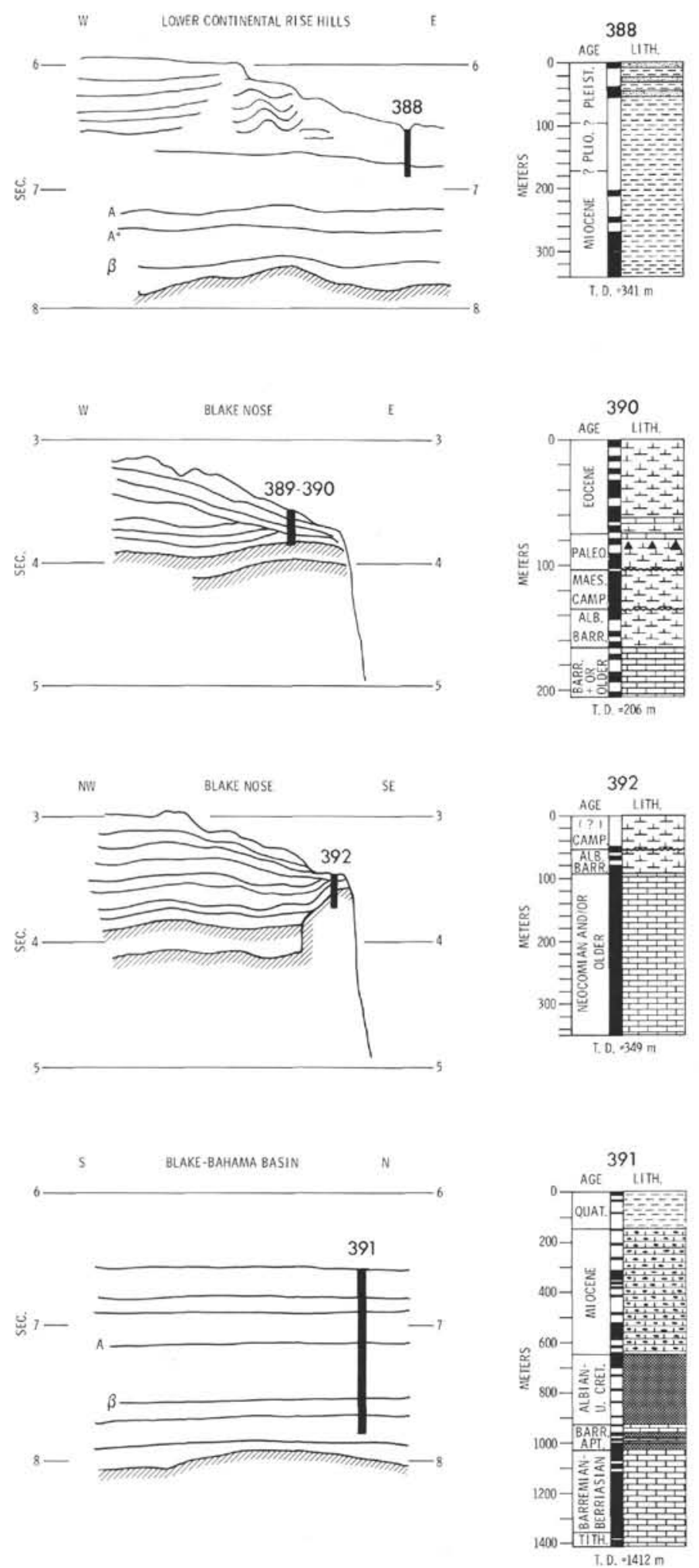

LEGENO

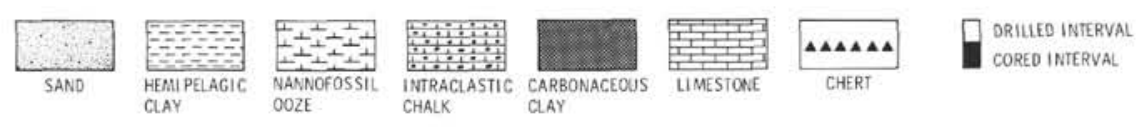

Figure 1. (Continued). 
bulk sediment, (3) particle-size distribution analysis of the fine fraction (grain size $<63 \mu \mathrm{m}$ ), (4) silt mineralogy $(20 \mu \mathrm{m}$ $<\mathrm{d}<63 \mu \mathrm{m})$, and (5) clay minerals determination $(\mathrm{d}<2$ $\mu \mathrm{m})$.

The sample volume was between 10-20 cc. Sediment analyses were made according to the following procedure (outlined in Figure 2). The bulk sediment was dried at about $60^{\circ} \mathrm{C}$ and sieved through a $63 \mu \mathrm{m}$ mesh to separate the coarse and fine fractions. The coarse fraction was then dried and weighed. The coarser particles $(\Theta>125 \mu \mathrm{m})$ were later separated by sieving. About 300 to 800 grains per sample were counted and separated in several classes using a stereomicroscope with incident light. This method was developed by Sarnthein (1971), and Thiede (1974). The various components are given in Table 2.

The mineralogy of the bulk silt fraction $(63>\phi>20 \mu \mathrm{m})$ was studied with a Siemens X-ray diffractometer. The mineralogy of the clay fraction $(<2 \mu \mathrm{m})$ was studied through disaggregated, decalcified, and oriented samples with a CGR X-ray diffractometer (Chamley, 1971).

The calcium carbonate $\left(\mathrm{CaCO}_{3}\right)$ content was determined by a Bernard calcimeter.

Grain size distribution analyses were performed with an electronic particle counter (Coulter counter T A type). The measured particle dimension is the volume diameter (the diameter of a sphere of equivalent volume). Using this method we considered the range of dimension between 1.7 and $56 \mu \mathrm{m}$. The curves were corrected for the amount of coarse fraction by assuming that the $63-\mu \mathrm{m}$ sieve dimension was equivalent to the $56-\mu \mathrm{m}$ volume diameter. Although this correction technique has not yet been thoroughly tested, apparently the approximation does not introduce an important discrepancy, in view of the generally low percentage of the coarse fraction.

From the cumulative curve parameters we determined the median, the mode, and the first and third quartiles from which two parameters were derived.

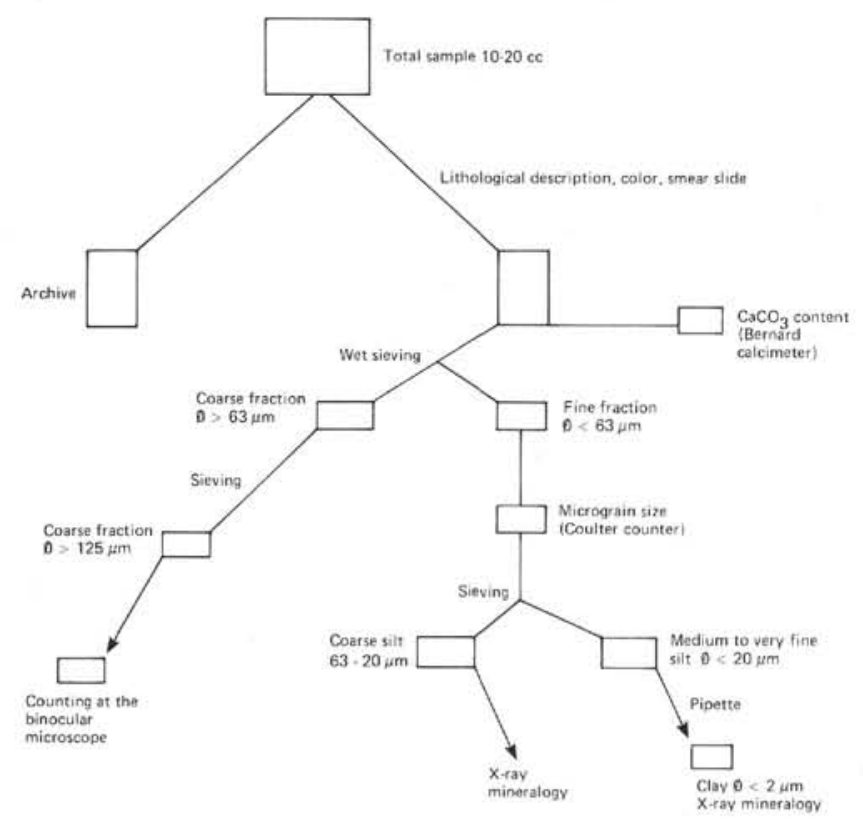

Figure 2. Flow chart showing steps in analytical procedure.
1) Trask sorting coefficient $\underline{\mathrm{SO}}=\sqrt{\frac{\mathrm{Q} 1}{\mathrm{Q} 2}}$
2) Trask skewness parameter $\underline{\mathrm{SK}}=\frac{\mathrm{Q} 1 \times \mathrm{Q} 3}{\mathrm{Md}^{2}}$

Skewness greater than 1 (coarse-tailed distribution) indicates better sorting of the fine particles; whereas skewness value less than 1 (fine-tailed distribution) indicated a better sorting of the coarse particles.

After we calculated the skewness parameter, we plotted all the data on a sorting-skewness diagram, using different symbols to indicate the mean size of the sediment. This allows us to distinguish empirically six "volumes" that correspond to six types of dominant sedimentary processes (Figure 3). We characterize these six types of processes and refer to them in the discussion of the sediments of the four sites.

Folk (1968) established a scale of sorting values for gravel to silt deposited mostly in shallow water environments. According to his classification most of the deep-sea sediment we studied is poorly sorted to very poorly sorted. In order to more accurately characterize the different types of sediment, we have adopted a different scale comprising five classes:

$$
S O<1.7 \text { - very well sorted }
$$

$1.7<S O<2$ - well sorted

$2<S O<2.3$ - moderately well sorted

$2.3<S O<2.6$ - poorly sorted

$2.6<S O$ - very poorly sorted

With regard to skewness we have adopted the following classification.

$$
\begin{aligned}
S K & <0.75 \text { strongly fine tailed } \\
0.75 & <S K<0.9 \text { fine tailed } \\
0.9<S K & <1 \text { moderately fine tailed } \\
1< & <S K<1.1 \text { moderately coarse tailed } \\
1.1< & <K<1.25 \text { coarse tailed } \\
& S K>1.25 \text { strongly coarse tailed }
\end{aligned}
$$

The average size of the sediment according to the median was distinguished following the Wentworth (1922) size classification:

$$
\begin{aligned}
\mathrm{Md} & >31 \mu \mathrm{m} \text { coarse silt } \\
15 \mu \mathrm{m}<\mathrm{Md} & <31 \mu \mathrm{m} \text { medium silt } \\
8 \mu \mathrm{m}<\mathrm{Md} & <15 \mu \mathrm{m} \text { fine silt } \\
4 \mu \mathrm{m}<\mathrm{Md} & <8 \mu \mathrm{m} \text { very fine silt }
\end{aligned}
$$

Different micrograin size types were distinguished on the basis of micrograin size as follows:

Type I: Very fine to fine silt, moderately well to very well sorted, moderately fine-tailed to coarse-tailed distribution pattern. The relatively fine texture and the rather symmetrical distribution with a tendency toward coarse-tailing suggests that this type of particle-size distribution could be the result of deposition from a very gentle bottom current.

Type II: Medium silt, very well to moderately well sorted, moderately fine-tailed to coarse-tailed distribution pattern. This microfacies differs from type I only by being coarser and thus would result from more active bottom current circulation.

Type III: Fine to medium silt, well to very poorly sorted, strongly fine-tailed to moderately coarse-tailed distribution pattern. A great variety of sediment types fall into this category. They can be distinguished from types I and II, either by poorer sorting or the tendency toward strong fine 
TABLE 2

Occurrence of Various Terrigenous, Authigenic and Biogenic Components Distinguished in This Study

\begin{tabular}{lllll}
\hline Terrigenous Components & Authigenic Components & $\begin{array}{c}\text { Biogenic Calcareous } \\
\text { Components }\end{array}$ & $\begin{array}{c}\text { Biogenic Siliceous } \\
\text { Components }\end{array}$ & $\begin{array}{c}\text { Miscellaneous Biogenic } \\
\text { Components }\end{array}$ \\
\hline Colorless quartz & Glauconite & Plankton & Radiolarians & Plants \\
Reddish quartz & Pyrite & Foraminifers, ptero- & $\begin{array}{l}\text { Diatoms } \\
\text { Sponge spicules }\end{array}$ & Fish \\
Mica & Manganiferous oxide & $\begin{array}{l}\text { pods, ostracodes } \\
\text { Other minerals }\end{array}$ & Benthos & \\
Rock fragments & & Foraminifera, & \\
Muddy aggregates & Echinoids & \\
& Ostracodes & \\
& Bryozoa & \\
& Gastropods & \\
& Corals & \\
& Bivalves & \\
& Miscellaneous & \\
& & \\
\end{tabular}

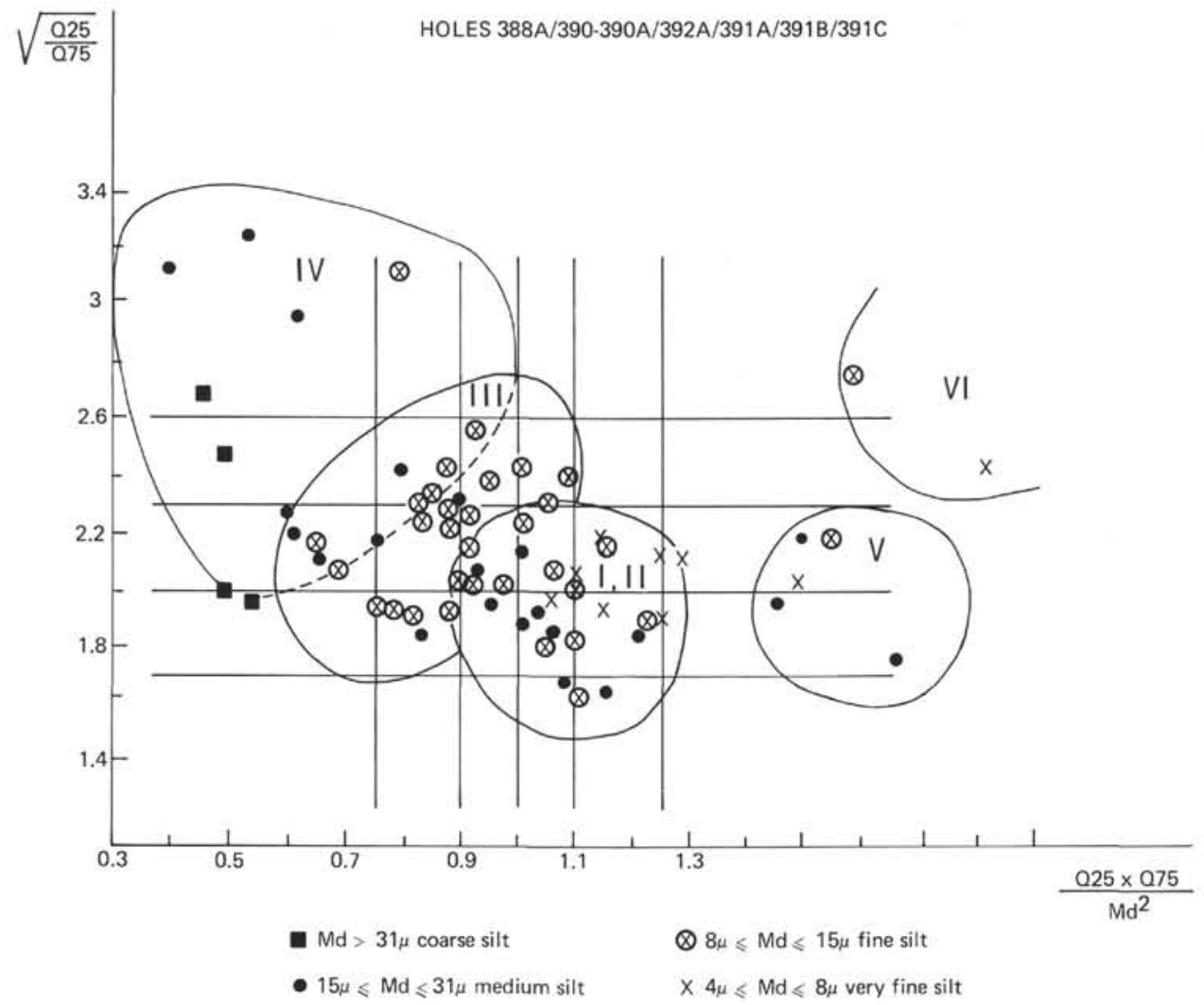

Figure 3. Distribution of samples from all sites into microfacies on the basis of micrograin size types.

tailing, or both. Although these could correspond to a great variety of sedimentary processes, we keep them in the same category because they all imply influence by turbidity currents (of high or low density). The complexity of turbidity current deposition itself could perhaps explain the observed disparity, but we think that interaction with contour currents may also be responsible for part of the variation.

Type IV: Medium to coarse silt, poorly to very poorly sorted, fine-tailed to strongly fine-tailed distribution patterns. This microfacies seems to us typical of deposition from high density turbidity currents.

Type V: Very fine to medium silt, moderately well to well sorted, strongly coarse-tailed distribution patterns.
Sediments of this type could correspond to deposition processes in the absence of active bottom current.

Type VI: Very fine to fine silt, poorly to very poorly sorted, strongly coarse tailed distribution pattern. Pelagic foraminifer-nannofossil ooze deposits comprise this type of microfacies.

The distribution of the Leg 44 samples into the six microfacies types is shown in Figure 3.

\section{Site $\mathbf{3 8 8}$}

\section{RESULTS}

Site 388 is located in 4919 meters of water on the North American continental rise in a region characterized by 
TABLE 3

Summary of Coarse Fraction Components, Grain Size, and Mineralogic Results, Site 388

\begin{tabular}{|c|c|c|c|c|c|c|c|c|c|c|c|c|c|c|c|c|}
\hline \multirow[b]{2}{*}{$\begin{array}{c}\text { Sample } \\
\text { (Interval in } \mathrm{cm} \text { ) }\end{array}$} & \multirow[b]{2}{*}{ 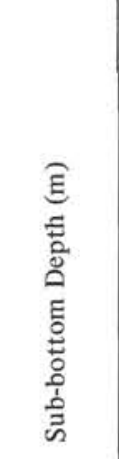 } & \multirow[b]{2}{*}{ 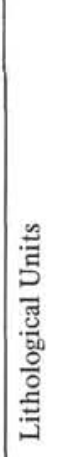 } & \multirow[b]{2}{*}{ 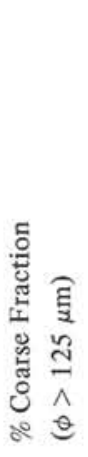 } & \multirow[b]{2}{*}{ 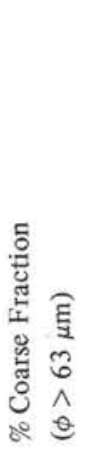 } & \multicolumn{9}{|c|}{$\%$ Coarse Fraction Compounds } & \multirow[b]{2}{*}{ 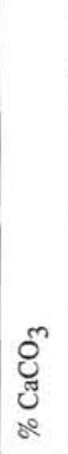 } & \multicolumn{2}{|c|}{ Grain } \\
\hline & & & & & 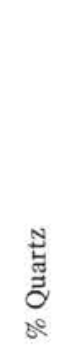 & 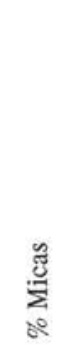 & 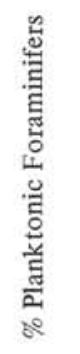 & 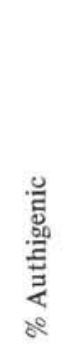 & 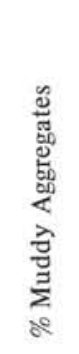 & 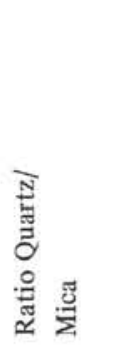 & 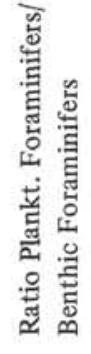 & 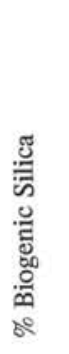 & $\begin{array}{l}0 \\
\stackrel{0}{5} \\
0 \\
0\end{array}$ & & 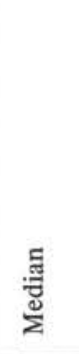 & 号 \\
\hline $1-3,103-105$ & 4.03 & 1 & 4.8 & 10.9 & 43.0 & 3.7 & 40.0 & 0.3 & & 11.62 & 23.5 & & 13.0 & 35 & 18 & 3.35 \\
\hline $2-1,140-142$ & 38.40 & 1 & 0.4 & 0.8 & 3.6 & 0.9 & 73.0 & 3.2 & 15.0 & 4.0 & 40.5 & & 7.3 & 19 & 13 & 3.16 \\
\hline $2-3,80-82$ & 41.30 & 1 & 0.1 & 0.2 & 0.4 & 5.2 & 84.6 & 1.7 & 1.7 & 0.08 & 76.9 & 0.6 & 5.8 & 7 & 9.5 & 2.31 \\
\hline $2-3,120-122$ & 41.70 & 1 & 0.06 & 0.1 & 0.2 & 2.1 & 75.3 & 0.6 & 17.5 & 0.10 & 94.1 & 0.2 & 4.1 & 7 & 8.0 & 2.24 \\
\hline $5-1,2-4$ & 246.02 & 2 & 0.2 & 0.6 & 1.5 & 36.8 & 2.8 & 35.6 & 20.7 & 0.04 & $\infty$ & 0.1 & 2.5 & 3 & 18.0 & 2.10 \\
\hline $7-3,60-62$ & 297.10 & 2 & 0.2 & 0.7 & 1.9 & 19.8 & 2.1 & 35.5 & 38.2 & 0.10 & 10.5 & 0.3 & 2.2 & 4 & 18.0 & 1.83 \\
\hline $9-3,128-130$ & 316.78 & 2 & 0.4 & 0.5 & 0.2 & 4.4 & 3.0 & 88.0 & & 0.05 & 1.3 & & 4.4 & 7 & 14.0 & 2.37 \\
\hline $9-3,132-134$ & 316.82 & 2 & 0.4 & 0.7 & 0.1 & 1.3 & 2.5 & 31.7 & 61.5 & 0.08 & 1.9 & & 2.9 & 3 & 14.0 & 2.09 \\
\hline $9-6,21-23$ & 320.21 & 2 & 0.1 & 0.5 & 0.2 & 15.0 & 2.2 & 34.5 & 45.8 & 0.01 & 5.5 & 1.2 & 1.1 & 6 & 17.0 & 1.91 \\
\hline $10-1,131-133$ & 323.31 & 2 & 0.1 & 0.3 & 0.1 & 21.7 & 2.1 & 16.0 & 59.4 & 0.004 & $\infty$ & 0.1 & 0.6 & 3 & 12.5 & 1.94 \\
\hline $11-2,110-112$ & 334.10 & 2 & 0.2 & 0.3 & 0.2 & 3.8 & 2.0 & 36.1 & 43.2 & 0.05 & 3.3 & & 14.7 & 2 & 13.5 & 1.90 \\
\hline
\end{tabular}

abyssal hills. The sub-bottom penetration was only 341 meters owing to failures in the drilling and coring systems. Two lithologic units were distinguished:

Unit $1(53.5 \mathrm{~m})$ upper Pleistocene olive-gray (5Y 4/1) calcareous silty clay, marly ooze, sand, and silt.

Unit $2(133 \mathrm{~m})$ is more uniform and consists of upper to middle Miocene, dark greenish gray (5G 4/1) silty clay and clay which is stiffer in the lower part (Core 9 to Core 11).

Preliminary shipboard examinations of unit 2 suggested that the sediment deposition was current controlled. The sediments of this unit correspond to undulated seismic levels which lie above the middle Miocene seismic reflector $X$, These topographic features could be the result of sediment deposition from contour currents. Sediment of unit 1 disconformably blankets this undulating topography. These layers could be Pliocene sediments deposited by turbidity currents and/or contour currents.

\section{Sedimentological Results}

Several representative samples of the two units were studied. Unit 1 is marly nannofossil ooze, calcareous mud, and mud in which the $\mathrm{CaCO}_{3}$ content ranges between 7 per cent and 25 per cent. The coarse fraction $(\phi>63 \mu \mathrm{m})$ content ranges between 10.9 per cent and 0.1 per cent. Unit 2 is mud, mudstone, and claystone; $\mathrm{CaCO}_{3}$ contents range between 3 per cent and 7 per cent and the coarse fraction $(V>$ $63 \mu \mathrm{m}$ ) content ranges between 0.3 per cent and 0.7 per cent. The data are presented in Table 3.

\section{Examination of the Coarse Fraction $(0>125 \mu \mathrm{m})$}

This coarse fraction is rather sparse $(0.06 \%$ to $0.4 \%)$ except for the uppermost sample $(388-1-3,103-105 \mathrm{~cm})$ where it reaches 4.8 per cent. This sample is characterized by the abundance of detrital, colorless or reddish quartz grains $(43 \%)$. In the other samples the quartz content ranges between 0.1 and 3.6 per cent. Micaceous grains are abundant principally in the Miocene sediments where they form from 1.3 per cent to 37.0 per cent of the sediment. Planktonic foraminifers, both entire specimens and broken tests, are abundant in unit 1 ( $40.0 \%$ to $84.6 \%)$. The authigenic fraction represented by pyrite and traces of glauconite, forms a large part of the samples from unit 2 (16.0\% to $88.0 \%)$.

\section{Mineralogy}

The silt fraction $(63 \mu \mathrm{m} \phi>20 \mu \mathrm{m})$ consists almost entirely of quartz with traces of feldspar and mica. Sample 388-1-3, 103-105 cm which contains calcite is an exception.

The clay fraction $(\phi<2 \mu \mathrm{m})$ is distinctly different in samples of the two units. Unit 1 is characterized by the occurrence of illite $(40 \%)$, smectite $(30 \%)$, chlorite $(25 \%)$, kaolinite (10\%), and mixed-layered clay minerals (traces), whereas unit 2 is characterized by the abundance of smectite $(90 \%)$ and the scarcity of illite (5\%) and kaolinite (5\%). (These values are averages.)

\section{Micrograin Size Analyses}

Samples are grouped under micrograin size types as follows (Figure 4):

Type I: Samples $2-3,80-82 \mathrm{~cm}, 2-3,120-122 \mathrm{~cm}$, Pleistocene mud. Samples were taken from a laminated zone. There is very little coarse fraction in these samples and it is characterized by the abundance of planktonic foraminifer tests.

Type II: Samples 5-1, 2-4 cm, 9-6, 21-23 cm, Miocene mud 
TABLE 3 - Continued

\begin{tabular}{|c|c|c|c|c|c|c|c|c|c|c|c|c|c|}
\hline \multicolumn{2}{|c|}{ Size } & \multicolumn{3}{|c|}{$\begin{array}{c}\text { Silt } \\
\text { Mineralogy }\end{array}$} & \multicolumn{6}{|c|}{$\%$ Clay Minerals } & \multirow[b]{2}{*}{ Lithology } & \multirow[b]{2}{*}{ Structure } & \multirow[b]{2}{*}{ Age } \\
\hline 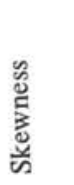 & 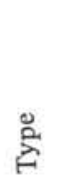 & 营 & 营 & 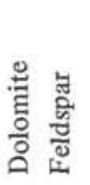 & 兽 & 䒿 & 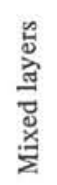 & 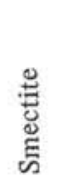 & 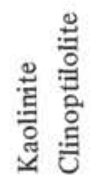 & 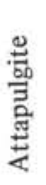 & & & \\
\hline 0.53 & IV & H & +++ & & 40 & 30 & & 30 & & & Marly nannofossil ooze & Turbidite & Pleistocene \\
\hline 0.77 & IV & ++ & + & & 40 & 25 & + & 35 & + & & Calc. clay & Mottled & Pleistocene \\
\hline 1.05 & I & $H+$ & + & + & 35 & 25 & + & 30 & 10 & & Calc. silty clay & Mottled & Pleistocene \\
\hline 1.01 & I & n+ & & & 40 & 25 & + & 25 & 10 & & Calc. silty clay & Mottled & Pleistocene \\
\hline 0.91 & II & H+ & & + & 5 & + & & 90 & 5 & + & Silty clay & Finely mottled & Upper Miocene \\
\hline 0.83 & III & H+ & & + & + & + & & 95 & 5 & & Clay & Finely mottled & Upper Miocene \\
\hline 0.84 & III & H+ & & + & + & + & & 95 & 5 & + & Stiff clay & Mottled & Upper Miocene \\
\hline 1.67 & III & + & & & 5 & & 5 & 85 & 5 & & Stiff clay & Mottled & Upper Miocene \\
\hline 1.03 & II & H+ & & & 5 & + & & 90 & 5 & & Stiff clay & Mottled & Middle Miocene \\
\hline 0.75 & III & ++ & & & + & + & & 95 & 5 & & Stiff clay & Mottled & Middle Miocene \\
\hline 0.81 & III & ஓ ฐี & ஓ శึં & + & + & + & & 95 & 5 & + & Stiff clay & & Middle Miocene \\
\hline
\end{tabular}

and mudstone. These samples were taken from the mottled part of the core. There is very little coarse fraction which comprises a few planktonic foraminifer tests.

Type III: Samples 7-3, 60-62 cm, 9-3, 128-130 cm, 9-3, $132-134 \mathrm{~cm}, 10-1,131-133 \mathrm{~cm}, 11-2,110-112 \mathrm{~cm}$, Miocene mudstone and claystone. These sediments are finely mottled and have a few laminations. There is very little coarse fraction and it is devoid of planktonic foraminifer tests.

Type IV: Samples 1-3, 103-105 cm, 2-1, 140-142 cm, Pleistocene marly ooze and calcareous clay. These strata are characterized by a homogeneous structure or very diffuse layering. The relatively large amounts of coarse fraction and its composition suggest that the sediment may have been deposited by turbidity currents.

\section{Discussion}

The occurrence of a middle Miocene acoustic layer $X$ is discussed in the Site 388 Report, this volume. Below this horizon the acoustic layers appear to be sub-parallel or parallel. In contrast, the overlying sediment surfaces are undulated which could be related to current-controlled depositional processes. However, sorting and skewness of the sediments sampled in Cores 9 to 11 which apparently were recovered from below layer $X$, suggest that they were deposited from turbidity and/or contour currents (types II and III), as well as the sediment sampled between Cores 5 to 7 above reflector $X$. More analyses are necessary to confirm this. The abundance of smectite during the Miocene is significant. It could account for as much as 90 per cent of the total sediment from this period. If the sediments were deposited by turbidity currents, as suggested above, then the smectite is partially or totally of continental origin. But the reasons for such large amounts of smectite are not clear (pedogenetic processes, volcanic influence, or hydraulic segregation) and an intrabasinal origin cannot be disregarded. Contour currents seem to have been active during part of the Pleistocene (type I) and possibly through the Pliocene (no Pliocene was recovered but there is a gap in the recovery between $53.5 \mathrm{~m}$ to $208.0 \mathrm{~m}$ ). Deposition from turbidity currents was also important during the Pleistocene (type IV) and can explain the decrease in smectite in the uppermost two samples. Moreover, the world cooling which occurred in the late Cenozoic largely determined the increase of primary minerals (illite, chlorite) supplied from continental erosion, inducing a decrease in smectite content.

\section{Site 390}

Two holes, 390 and $390 \mathrm{~A}$, were drilled at this site in 2670 meters water depth; the sub-bottom depth was 206 meters. Drilling at these holes provided a sedimentary sequence ranging from Barremian (or older) to middle Eocene. Eight lithologic units were recognized. The uppermost unit consists of a manganese veneer, the age of which is difficult to estimate, but which seems to be slightly younger than the middle Eocene unit below. Drilling penetrated to a massive limestone of at least Barremian age which contains numerous benthic organisms. This unit constitutes the eighth and lowermost lithologic unit. The remaining six units consist of lower Albian to middle Eocene nannofossil ooze. Two major hiatuses occurred: one between lower Albian and upper Campanian and the other between middle Maestrichtian and lower Paleocene. The lowermost hiatus correlates with a 


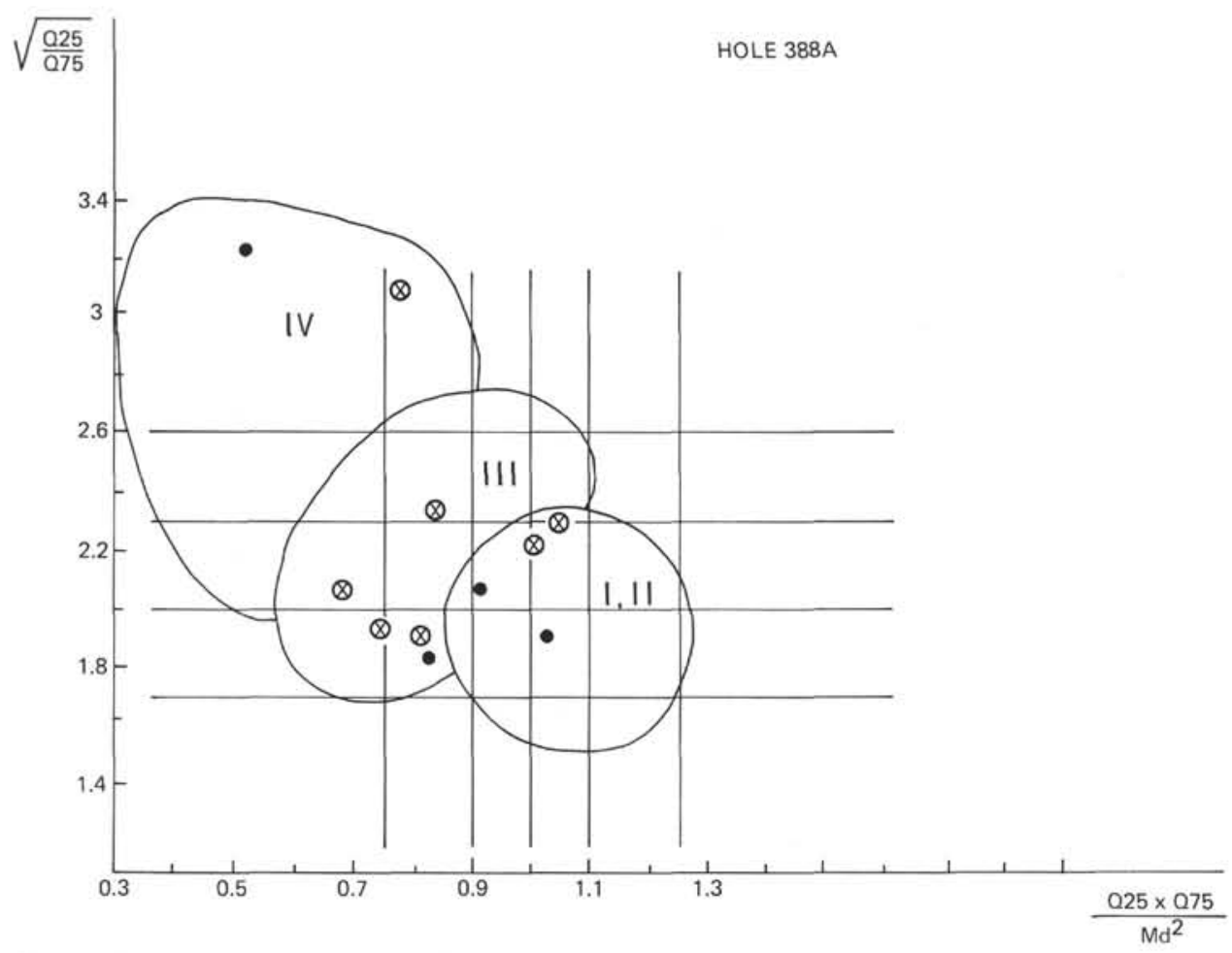

Figure 4. Micrograin size type (microfacies) of Site 388 samples.

seismic reflector at 0.19 second two-way travel time that constitutes a major angular unconformity.

Thirty-four samples were taken in the nannofossil ooze units. Five samples were taken in unit 2 which comprises 47 meters of middle Eocene white (5Y 8/2) to pale brown (10YR $7 / 4$ ) nannofossil ooze. This upper part of this unit is finely laminated (Hole 390, Core 1, Section 3 and Section 6).

Eight samples were taken from unit 3, 43 meters thick, which consists of nannofossil ooze and contains a few layers of chalk, cherty limestone, and intervals of lithified siliceous limestone. Sediment colors vary from very pale brown (10YR 8/3, 8/4, 7/3) to light yellowish brown (10YR 6/4) and pale yellow ( 5 Y 8/3). The 24 meter thick sub-unit $3 \mathrm{a}$ of lower Eocene sediments contains more siliceous debris (18\%) than the 19 meter thick sub-unit $3 \mathrm{~b}$ (lower Eocene to upper Paleocene) characterized by the occurrence of cherts layers. Mottling is common.

Six samples were taken from unit 4 (17.4 m thick) of lower Paleocene light brownish gray (10YR 6/2), light gray (10YR $7 / 2$ ), and white (10YR 8/2) zeolitic nannofossil ooze. The zeolite content, estimated from smear-slide examination, is about 9 per cent.

Six samples were taken from unit 5 Maestrichtian sediments in which two sub-units were distinguished: sub-unit $5 \mathrm{a}$ ( $13.1 \mathrm{~m}$ thick) consists of greenish gray ( $5 \mathrm{G} 8 / 1$, $7 / 1$ ) or light bluish gray (5B 7/1) nannofossil ooze. It contains 20 per cent clay materials; sub-unit $5 \mathrm{~b}$ ( $7.5 \mathrm{~m}$ thick), consists of bluish gray (5B 7/2) nannofossil ooze, richer in $\mathrm{CaCO}_{3}$. Well-defined laminations occur in sub-unit 5a (Hole 390A, Core 12).

Three samples from unit 6 (6.7 $\mathrm{m}$ thick) consist of pale brown (10YR 8/3) lower Maestrichtian and upper Campanian nannofossil ooze.
Five samples from unit 7 (23 m thick) are variously colored (reddish brown, 5YR 4/4; red, 2.5YR 4/6; yellow, 5Y 8/5; pink, 5YR 7/3; pale yellow, 5YR 8/3; white, 5Y, 8/2; light gray, 10YR 7/2) nannofossil oozes of lower-middle Albian to upper Aptian sediments. Fine laminations occur sporadically.

\section{Sedimentologic Results}

Laboratory analyses confirm the high $\mathrm{CaCO}_{3}$ contents characteristic of the nannofossil oozes. They range from 70 per cent to 95 per cent except for samples from units $3 \mathrm{~b}$ and 4 that consist of marly nannofossil ooze and in Samples $390 \mathrm{~A}-14-5,140-142 \mathrm{~cm}$ and $390-3-2,118-120 \mathrm{~cm}$ from units 6 and 7 (marly nannofossil ooze and calcareous mud, respectively). Sedimentologic data for Site 390 is given on Table 4.

Coarse fraction $(\phi>63 \mu \mathrm{m})$ percentages are generally lower than 10 per cent except for one sample from unit 3 (390A-4-6, 91-93 cm) where it is about 30 per cent.

$$
\text { Examination of the Coarse Fraction }(\phi>125 \mu \mathrm{m})
$$

The main results are as follows.

1) The terrigenous fraction (quartz and mica) is scarce. The highest quartz value is close to 1 per cent in Sample $390-3-2,118-120 \mathrm{~cm}$ from unit 6 (calcareous mud). Mica generally comprises less than 1 per cent. The highest values appear in Samples 390A-11-5, 76-78 cm, unit 4; 390A-11-6, $85-87 \mathrm{~cm}$, unit 5; 390A-14-5, 140-142 cm, unit 7.

2) Entire or broken planktonic foraminifer tests are very abundant (average content is $>70 \%$ ) except where they are diluted by siliceous organisms or muddy aggregates.

3) Siliceous organisms (sponge spicules and particularly 
radiolarians) are locally abundant ( $3 \%$ to $85 \%)$ in unit 2 and 3a samples.

4) Authigenic material is scarce. It consists mainly of manganese micronodules and a few pyritic grains. The greatest amount of authigenic material (3.9\%) occurs in Sample 390A-10-1, 110-112 cm.

5) Muddy aggregates are abundant in Samples 390-3-2, $118-120 \mathrm{~cm}$ and $4-2,117-119 \mathrm{~cm}(22.5 \%$ and $14.0 \%)$.

\section{Mineralogy}

The silt fraction mineralogy is characterized by the abundance of calcite and occurrence of quartz from Sample $390 \mathrm{~A}-8-4$, 130-132 cm (sub-unit 3) to Sample 390-4-2, $117-119 \mathrm{~cm}$, (unit 7).

The presence of smectite characterizes the clay fraction. But the amounts of smectite fluctuate greatly throughout the recovered sedimentary column. It is rare or common from Aptian to upper Maestrichtian and becomes very abundant (up to $90 \%$ ) in the uppermost layers of the recovered Maestrichtian (390A-12-2, 130-132 cm). Low and medium smectite contents are associated with extremely variable amounts of kaolinite ( $5 \%-40 \%)$ mixed-layered clays, chiefly illite-smectite (traces to 20\%), illite (4\%-50\%), and occasionally chlorite $(0 \%-5 \%)$. Serpentine is possibly present in the lower Albian sample, 390-4-1, 123-125 cm. Clinoptilolite is common in samples from the Paleocene to Eocene. High smectite contents are associated with very low amounts of illite and sometimes kaolinite and/or chlorite.

\section{Micrograin Size Analyses}

Figure 5 shows sorting versus skewness of the Site 390 samples. These are distributed under migrograin size types as follows.

Type I: Samples 390-1-3, 50-52 cm; 390A-13-2, 32-34 cm; $390-3-2,118-120 \mathrm{~cm}$; 390-3-3, 140-142 cm; and 390-4-2, $117-119 \mathrm{~cm}$. These samples are laminated, layered, or homogeneous nannofossil ooze and marly nannofossil ooze belonging to lithological units $2,5,6$ and 7 .

Type II: Samples 390-1-6, 140-142 cm; 390A-3-4, 115-117 cm; 390A-6-2, 10-12 cm; 390A-7-4, 120-122 cm;390A-8-4, $40-42 \mathrm{~cm}$; 390A-8-4, 130-132 cm; 390A-10-1, 110-112 cm; $390 \mathrm{~A}-10-3,60-62 \mathrm{~cm}$; and $390 \mathrm{~A}-10-5,10-12 \mathrm{~cm}$. These sediments are mainly nannofossil ooze with some sedimentary structures (such as layering, laminations, mottling), and also siliceous nannofossil ooze. These samples belong to lithologic units $2,3 \mathrm{a}, 3 \mathrm{~b}$, and 4 .

Type III: Samples 390A-9-1, 143-145 cm; 390A-11-3, 90-92 cm; 390A-11-5, 76-78 cm; 390A-11-6, 85-87 cm; 390A-12-2, 130-132 cm; 390A-12-6, 143-145 cm; 390A-13-3, 80-82 cm; 390A-14-2, 70-72 cm; 390A-14-4, $70-72 \mathrm{~cm}$; 390-4-1, $123-125 \mathrm{~cm}$; and 390-5-2, $26-28 \mathrm{~cm}$. These sediments are homogeneous or mottled calcareous chalk, layered nannofossil ooze, and homogeneous or mottled marly nannofossil ooze. Some of the samples belong to lithological units $3 \mathrm{~b}$ and 7 , but most of them belong to units 5 and 6.

Type V: Samples 390A-4-6, 91-93 cm; 390A-8-2, 4-6 cm; $390 \mathrm{~A}-8-2,130-132 \mathrm{~cm}$; and 390A-14-5, 140-142 cm. These are mostly nannofossil ooze and chalk samples of sub-units $3 \mathrm{a}$ and $3 \mathrm{~b}$; one sample was from unit 7 .

\section{Discussion}

The sediments recovered at Holes 390 and 390A were deposited in a bathyal environment at about 500 meters depth or more (see Site 390 Report, this volume). Although protected from the influx of coarse terrigenous sediments, large amounts of silty and clayey terrigenous components were supplied.

The Middle to Upper Cretaceous (Aptian to Maestrichtian) was characterized by a relatively weak water circulation (type I) with an occasional influx of sediments from (low density?) turbidity currents (type III). Significant hiatuses occur in sediments deposited during this time. The most important hiatus occurs between the middle Albian and upper Campanian (time gap $=30 \mathrm{~m} . \mathrm{y}$.). The hiatus may be related to a period of intensification of the circulation (Site 390 Report, this volume). The second hiatus, between upper Maestrichtian and Paleocene (time gap $=7 \mathrm{~m} . \mathrm{y}$.), is perhaps more clearly related to current effects, inasmuch as the onset of active circulation by the beginning of Paleocene time is well known. The detrital and particularly clayey mineral contributions are extremely variable in Aptian to Maestrichtian sediments. These variations could either reflect changing sedimentary processes, tectonically rejuvenated, or be indicative of changing climatic and weathering conditions. Clay mineral assemblages suggest temperate warm and humid climates characterized by low hydrolysis conditions (illite dominant $40 \%$ to $50 \%$ ); it may have prevailed during late Aptian to early/middle Albian time.

During late Campanian to late Maestrichtian, we detected a climatic evolution toward increasing weathering conditions, even one conducive to lateritic formation clay mineral assemblages comprise abundant kaolinite (40\%), very badly crystallized smectite and mixed-layered clays, altered illite, rarely occurring non-clayey minerals, and the presence of goethite.

As stated previously, these mineralogical fluctuations, are not necessarily related directly to climatic events, but could as well result from a changing sedimentation regime and/or tectonic activity. During this time period, evidence of such changes are suggested by the different grain size type. The clay assemblage in upper Aptian to upper Campanian is characterized by abundant illite and would reflect temperate warm and humid climates with small hydrolysis. This clay mineralogical facies generally corresponds to type I, which is indicative of weak oceanic circulation. In contrast, the clay mineralogical facies, occurring in lower Maestrichtian and characterized by abundant kaolinite, which could reflect severe hydrolysis conditions (lateritic type) is associated with type III micrograin-size distribution. We interpret the type III facies as indicative of influence by turbidity currents. A main mineralogical change - a sudden increase in the abundance of smectite - occurred by upper Maestrichtian. This change is not accompanied by variations in the sedimentary deposition processes (turbidity current regime) and suggests that smectite has a nearby origin (volcanic alteration product and/or ?pedogenetic origin). Distinct changes in the sedimentary regime did not occur until early Paleocene in conjunction with the initiation of an intense oceanic 
TABLE 4

Summary of Coarse Fraction Components, Grain Size, and Mineralogic Results, Site 390

\begin{tabular}{|c|c|c|c|c|c|c|c|c|c|c|c|c|c|c|c|c|c|c|}
\hline \multirow[b]{2}{*}{$\begin{array}{c}\text { Sample } \\
(\text { Interval in } \mathrm{cm})^{\mathrm{a}}\end{array}$} & \multirow[b]{2}{*}{ 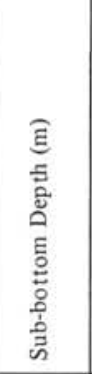 } & \multirow[b]{2}{*}{ 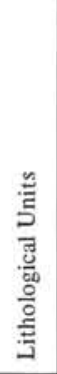 } & \multirow[b]{2}{*}{ 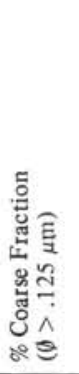 } & \multirow[b]{2}{*}{ 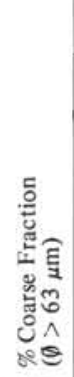 } & \multicolumn{9}{|c|}{$\%$ Coarse Fraction Components } & \multirow[b]{2}{*}{ 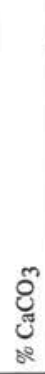 } & \multicolumn{4}{|c|}{ Grain Size } \\
\hline & & & & & 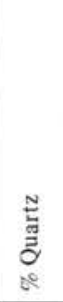 & 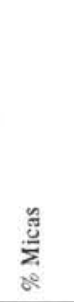 & 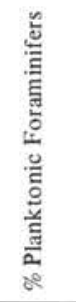 & 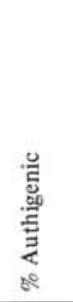 & 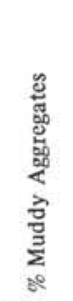 & 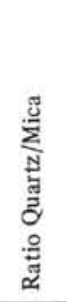 & 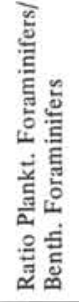 & 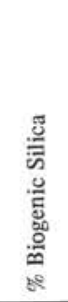 & 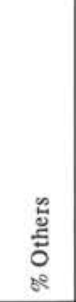 & & 莺 & 营 & 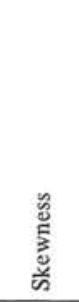 & $\stackrel{0}{\stackrel{2}{*}}$ \\
\hline $1-3,50-52$ & 3.50 & 2 & 0.9 & 2.3 & 0.4 & 0.7 & 95.4 & 0.1 & & 0.5 & 954 & & 3.4 & 86 & 11.5 & 1.83 & 1.1 & I \\
\hline $1-6,140-142$ & 8.90 & 2 & 2.0 & 5.6 & - & 1.3 & 96.6 & 0.6 & & 0 & 966 & & 1.5 & 85 & 16.0 & 1.83 & 1.05 & II \\
\hline $1 \mathrm{~A}-1,120-122$ & 10.70 & 2 & 1.7 & 3.4 & 0.4 & - & 86.9 & & & $\infty$ & 869 & & 10.8 & 75 & No ana & lysis & & Not defined \\
\hline $2 \mathrm{~A}-2,145-147$ & 18.45 & 2 & 1.0 & 3.0 & 0.1 & 0.1 & 40.8 & & & 1 & 408 & 56.9 & 2.1 & 69 & 16.5 & 3.11 & 0.39 & Not defined \\
\hline $3 A-4,115-117$ & 34.15 & 2 & 4.9 & 9.3 & & 0.3 & 67.3 & & & 0 & 254 & 31.5 & 0.9 & 66 & 17.0 & 2.12 & 1.00 & II \\
\hline $4 A-6,91-93$ & 46.41 & $3 \mathrm{~A}$ & 24.1 & 30.5 & & & 96.1 & & & & $\infty$ & 3.3 & 0.6 & 72 & 27.0 & 2.19 & 1.48 & $\mathrm{v}$ \\
\hline $6 \mathrm{~A}-2,10-12$ & 58.60 & $3 \mathrm{~A}$ & 4.3 & 10.6 & & & 32.0 & & & & $\infty$ & 68.0 & 0 & 66 & 20.0 & 1.64 & 1.14 & II \\
\hline $7 \mathrm{~A}-4,120-122$ & 62.70 & $3 \mathrm{~A}$ & 81.9 & 7.1 & & 0.08 & 15.0 & 0.08 & & 0 & 187 & 84.7 & 0.1 & 45 & 14.0 & 1.63 & 1.10 & II \\
\hline $8 A-2,4-6$ & 77.54 & 3B & 11.7 & 22.1 & & 0.3 & 93.3 & 0.3 & & 0 & 49 & 1.6 & 4.5 & 74 & 18.0 & 1.98 & 1.46 & $\mathrm{v}$ \\
\hline $8 \mathrm{~A}-2,130-132$ & 78.80 & 3B & 6.2 & 11.8 & 0.2 & 0.2 & 95.8 & & & 1 & 479 & 0.2 & 3.6 & 64 & 18.0 & 1.78 & 1.65 & $\mathrm{~V}$ \\
\hline $8 \mathrm{~A}-4,40-42$ & 80.90 & 3B & 4.0 & 9.5 & 0.2 & & 97.8 & & & $\infty$ & $\infty$ & 0.2 & 1.8 & 60 & 18.0 & 1.81 & 1.22 & II \\
\hline $8 \mathrm{~A}-4,130-132$ & 81.80 & 3B & 3.0 & 7.1 & 0.1 & 0.1 & 97.4 & & & 1 & 324 & & 2.4 & 40 & 16.0 & 1.67 & 1.09 & II \\
\hline $9 \mathrm{~A}-1,143-145$ & 86.93 & 3B & 1.4 & 4.0 & 0.9 & & 74.3 & & & $\infty$ & 247 & 7.9 & 16.9 & 58 & 16.0 & 2.17 & 0.75 & III \\
\hline $10 \mathrm{~A}-1,110-112$ & 96.10 & 4 & 2.0 & 5.3 & 0.6 & 0.6 & 87.4 & 3.9 & & 1 & 54 & & 7.5 & 66 & 16.0 & 1.99 & 0.89 & II \\
\hline $10 \mathrm{~A}-3,60-62$ & 98.60 & 4 & 2.3 & 9.2 & 0.2 & & 97.2 & & & $\infty$ & 972 & 0.1 & 2.5 & 67 & 15.0 & 1.87 & 1.00 & II \\
\hline $10 \mathrm{~A}-5,10-12$ & 101.10 & 4 & 3.5 & 11.0 & & & 94.1 & & & & 941 & & 5.9 & 49 & 16.0 & 1.94 & 0.94 & II \\
\hline $10 \mathrm{~A}-6,110-112$ & 103.60 & 4 & 1.7 & 6.7 & & 0.6 & 96.7 & & & 0 & 241 & & 2.7 & 55 & 21.0 & 2.12 & 0.65 & Not defined \\
\hline $11 \mathrm{~A}-3,90-92$ & 108.40 & 4 & 1.0 & 4.5 & & & 95.5 & & 2.6 & & 955 & & 1.9 & 56 & 15.0 & 2.35 & 0.88 & III \\
\hline $11 \mathrm{~A}-5,76-78$ & 111.26 & 4 & 0.01 & 0.4 & 0.2 & 3.2 & 92.1 & & 0.3 & 0.06 & 102 & & 4.2 & 50 & 9.0 & 2.38 & 0.96 & III \\
\hline $11 \mathrm{~A}-6,85-87$ & 112.85 & 5 & 1.8 & 2.9 & 0.6 & 3.3 & 89.0 & & & 0.18 & 68 & & 7.1 & 76 & 12.5 & 2.22 & 0.92 & III \\
\hline $12 \mathrm{~A}-2,130-132$ & 116.80 & 5 & 1.8 & 3.0 & 0.2 & 0.4 & 97.1 & & & 0.5 & 485 & & 2.3 & 73 & 13.0 & 2.28 & 0.89 & III \\
\hline $12 \mathrm{~A}-6,143-145$ & 122.93 & 5 & 1.6 & 2.7 & & 0.4 & 96.4 & & & 0 & 120 & & 3. & 74 & 13.0 & 2.43 & 1.02 & III \\
\hline $2-1,130-132$ & 124.80 & 5 & 1.4 & 2.5 & & 0.2 & 98.4 & & & 0 & 196 & & 1.4 & 73 & 6.1 & 2.01 & 1.49 & Not defined \\
\hline $13 \mathrm{~A}-2,32-34$ & 125.32 & 5 & 1.6 & 2.7 & & 0.4 & 98.2 & & & 0 & 245 & & 1. & 71 & 9.4 & 2.06 & 1.06 & 1 \\
\hline $13 \mathrm{~A}-3,80-82$ & 127.30 & 5 & 1.5 & 2.7 & 0.3 & 0.6 & 97.8 & & & 0.5 & $\infty$ & & 1.3 & 91 & 12.5 & 2.37 & 0.83 & III \\
\hline $14 \mathrm{~A}-2,70-72$ & 135.20 & 6 & 7.4 & 11.0 & 0.2 & & 94.8 & 0.1 & 0.1 & $\infty$ & $\infty$ & & 4.8 & 88 & 14.0 & 2.59 & 0.93 & III \\
\hline $14 \mathrm{~A}-4,70-72$ & 138.20 & 6 & 3.8 & 6.2 & 0.2 & 0.5 & 96.3 & & & 0.4 & $\infty$ & & 3.0 & 92 & 12.0 & 2.31 & 0.82 & III \\
\hline $3-2,118-120$ & 135.68 & 6 & 0.2 & 1.0 & 1.0 & & 48.4 & & 22.5 & $\infty$ & 2 & & 28.1 & 26 & 6.3 & 1.20 & 1.28 & I \\
\hline $3-3,140-142$ & 137.40 & 7 & 1.2 & 2.7 & & & 71.3 & 0.4 & & & 22 & & 28.3 & 96 & 7.6 & 1.89 & 1.25 & I \\
\hline $14 \mathrm{~A}-5,140-142$ & 140.40 & 7 & 0.4 & 1.8 & 0.1 & 2.9 & 72.5 & & 6.0 & 0.03 & 17 & 1.5 & 15.2 & 41 & 9.0 & 2.24 & 1.54 & $\mathrm{~V}$ \\
\hline $4-1,123-125$ & 143.73 & 7 & 0.3 & 1.5 & 0.4 & & 85.8 & & & $\infty$ & 22 & & 13.8 & 83 & 13 & 2.2 & 0.89 & III \\
\hline 4-2, 117-119 & 145.17 & 7 & 0.1 & 0.3 & 0.1 & & 26.0 & & 14.0 & $\infty$ & $\infty$ & & 59.9 & 44 & 7.2 & 2.12 & 1.25 & I \\
\hline $5-2,26-28$ & 153.76 & 7 & 4.6 & 7.1 & & & 73.6 & & & & $\infty$ & & 26.4 & 88 & 12.8 & 2.14 & 0.64 & III \\
\hline $8-6.130-132$ & 189.30 & 8 & 23.4 & 28.4 & & & & & & & & & & 97 & 35.0 & 2.45 & 0.49 & Not defined \\
\hline
\end{tabular}

Note: + traces, ++ common, +++ dominant.

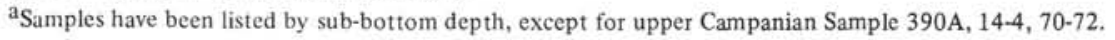

circulation (type II). This regime prevailed until middle Eocene. However, we have observed during late Paleocene periods a tranquil sedimentation regime (type V).

\section{Site 391}

This site is in the deepest part of Blake-Bahama Basin. Four holes, 391, 391A, 391B, and 391C, were drilled in 4923 meters water depth. The total sub-bottom penetration was 1412 meters. The hole penetrated Pleistocene/Holocene to Kimmeridgian or Tithonian sediments and rocks. Several lithological units were recognized.

Unit 1 (146.9 $\mathrm{m}$ thick) consists of Holocene/Pleistocene gray $(5 Y 5 / 1)$ to brown $(5 Y R 5 / 2)$ silty clay, with a small amount of nannofossil ooze and foraminifer sand.

Unit 2 (502.1 m thick) comprises a massive gravity flow deposit in which five sub-units were defined. Sediments 
TABLE 4 - Continued

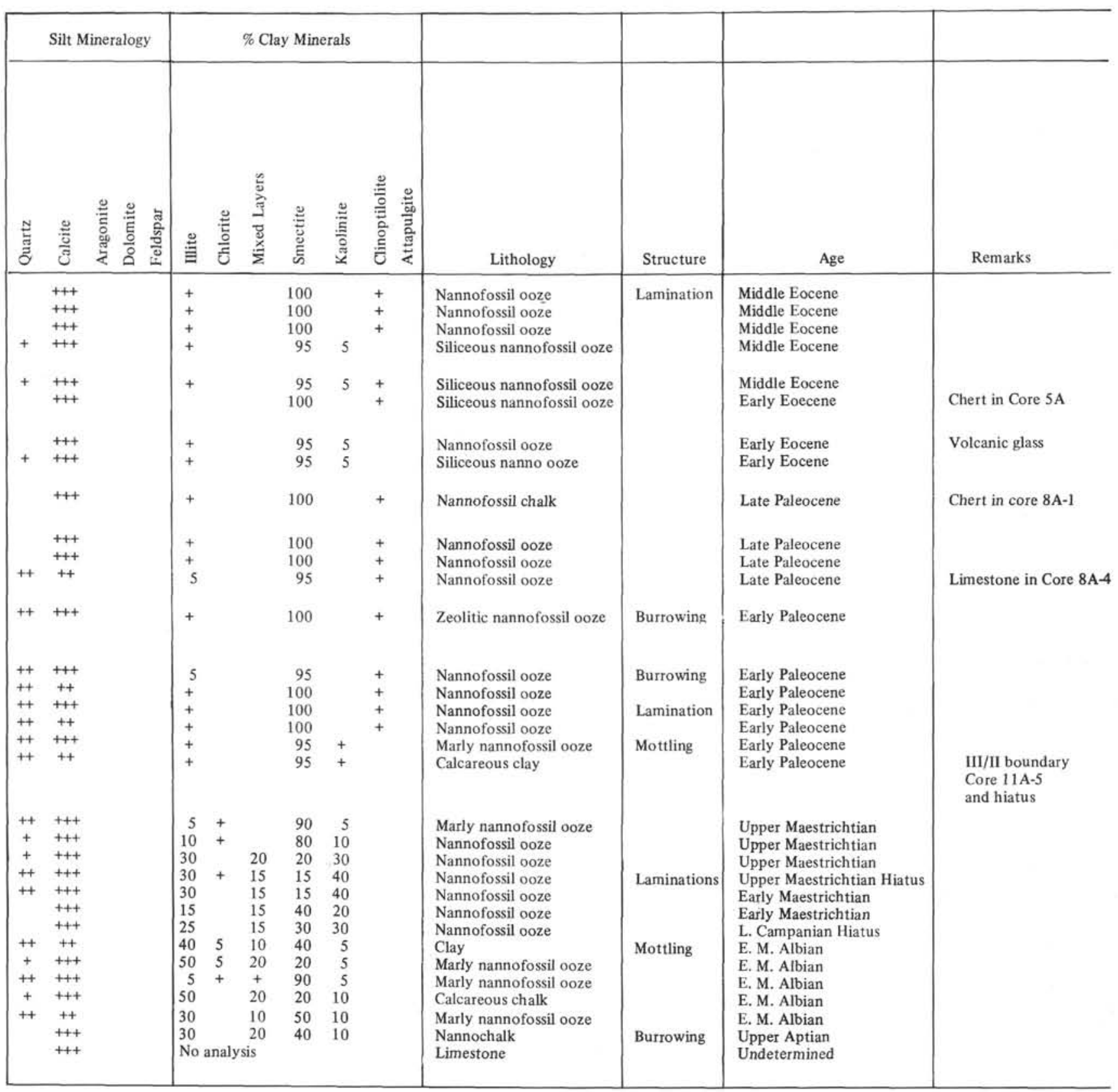

consist of white (5Y 8/1) silt-size carbonate containing few foraminifers and nannofossils. It is mainly pale olive (10Y $6 / 2$ ) chalk containing dark greenish gray $(5 \mathrm{G} 4 / 1)$ to medium bluish gray clasts of muddy siliceous ooze and radiolarian-rich sandstone and claystone.

Unit 3 (352.3 m thick) is Upper Cretaceous to Aptian variegated claystone and dark greenish gray $(5 \mathrm{GY} 4 / 1)$ or black (2.5YR N2.5) claystone overlying a carbonate transitional sequence.
Unit 4 (322.9 m thick) consists of limestone, mudstone, and shale divisible in four sub-units ranging from Hauterivian to Upper Tithonian. In sub-unit 4a cross-laminations indicate distal turbidites were deposited. Alternating light gray (5Y 6/1) to very dark gray (5Y 3/1) calcilutite and black ( $2.5 \mathrm{~N} 2.5)$ shales constitute sub-unit $4 \mathrm{~b}$. The other two sub-units are, respectively, bioturbated white (5.7YR N8) and dark greenish gray (5G 4/1) calcilutites, and white (7.5YR N8) to light bluish gray (5B 7/1) bioturbated 


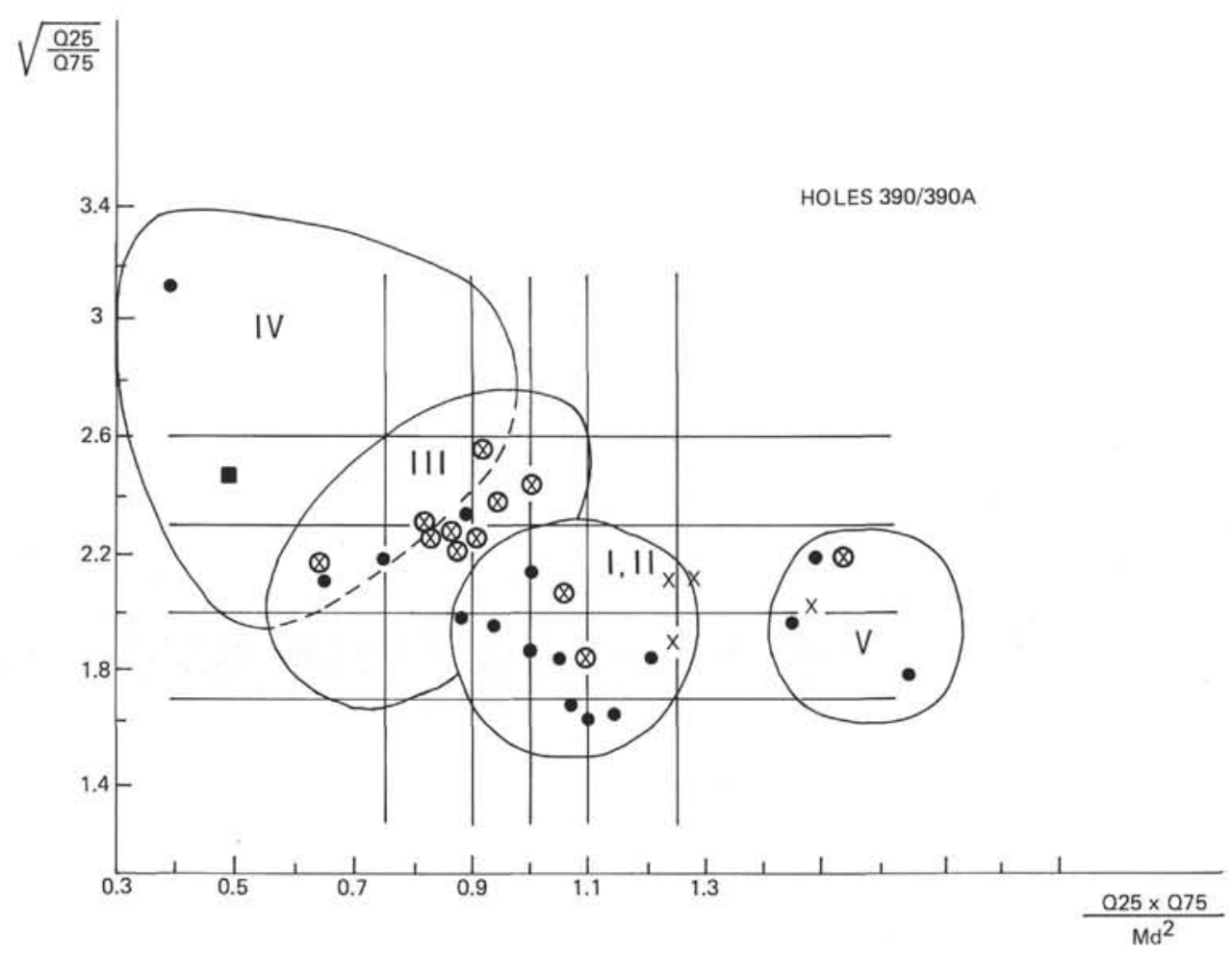

Figure 5. Micrograin size type (microfacies) of Site 390 samples.

calcilutites. The last sub-unit has stylolitic joints.

Unit $5(87.8 \mathrm{~m}$ thick $)$ is variegated pale red $(2.5 \mathrm{YR} 6 / 2)$, bluish white (5B 9/1), greenish gray (5GY 6/1) calcilutite, and dark reddish brown (5YR 3/2) marlstones which are separated into two sub-units. These deposits are lower Tithonian or upper Kimmeridgian.

Because most of the material at this site was indurated, only eleven samples were studied. Nevertheless, the sedimentological and mineralogical features are interesting.

\section{Sedimentological Results}

$\mathrm{CaCO}_{3}$ contents of the Pleistocene samples studied are low (4\%-10\%) except for Sample 391A-1-5, 53-55 cm, which contains 81 per cent $\mathrm{CaCO}_{3}$. Samples from the upper soft part of the allochthonous Miocene unit 2 (391A, Cores 3 and 4) show, in contrast, high $\mathrm{CaCO}_{3}$ contents (78\%-91\%). The Cretaceous carbonaceous claystone samples, 391A-21-1, $120-122 \mathrm{~cm}$ and 391C-4-1, 145-147 cm, contain 5 per cent $\mathrm{CaCO}_{3}$. Coarse fraction $(\phi>63 \mu \mathrm{m})$ contents vary greatly. They are generally small in Pleistocene deposits (0.4\%-0.8\%), except for Sample 391A-1-5, 53-55 cm. In upper Miocene sediments we distinguish two sediment types: in 391A, Core 3 (sub-unit 2a) coarse fraction percentages vary between 24 per cent and 30 per cent, whereas they are smaller $(1 \%-3 \%)$ in $391 \mathrm{~A}$, Core 4. Values in Samples $391 \mathrm{~A}-21-1,120-122 \mathrm{~cm}$ and $391 \mathrm{C}-4-1,145-147 \mathrm{~cm}$ from sub-unit $3 \mathrm{a}$ are lower than 1 per cent.

The sedimentological results are summarized on Table 5.

Examination of the Coarse Fraction $(\phi>125 \mu \mathrm{m})$

Particle counts were made only on Pleistocene samples; on Miocene and Cretaceous samples only qualitative estimations are given. Quartz is relatively scarce in the
Pleistocene samples, except for Sample 391A-3-1, 136-138 $\mathrm{cm}$ in which it forms 21.3 per cent of the sample. Micas range between 0.7 and 4 per cent in Pleistocene samples, and seem to be higher in the Cretaceous samples. The authigenic fraction contains glauconite, particularly in Sample $391 \mathrm{~A}-1-6,50-52 \mathrm{~cm}(12 \%)$, traces of pyrite, and manganiferous oxide. Gray muddy aggregates are abundant in Pleistocene Sample 391A-1-6, 50-52 cm. Siliceous skeletons (radiolarians, diatoms, sponge spicules) are present in all the samples and are more abundant in upper Miocene Hole 391A, Core 4 (radiolarians, sponge spicules).

\section{Mineralogy}

Silt fraction $(63 \mu \mathrm{m}>\phi>20 \mu \mathrm{m})$ mineralogy is characterized by the dominance of quartz in Pleistocene and Cretaceous sediments, except for Sample 391A-1-5, 53-55 $\mathrm{cm}$ in which calcite and aragonite occur. On the other hand, calcite is dominant in Miocene samples. Traces of dolomite occur in Miocene Sample 391A-3-5. The clay fraction $(\phi>2$ $\mu \mathrm{m})$ of the Pleistocene deposits is dominated by illite (35\%-50\%) in the uppermost samples (391B-1-4, 98-100 $\mathrm{cm} ; 391 \mathrm{~A}-1-5,53-55 \mathrm{~cm}$ ); in the lowermost part (391A-1-6, $50-52 \mathrm{~cm}$; 391A-3-1, 136-138 cm) smectite is dominant $(40 \%-45 \%)$, and associated minerals are chlorite, mixed-layered clays, and kaolinite. Smectite is very abundant (85\%-90\%) in Miocene samples, in which there are also traces of attapulgite. In Cretaceous samples smectite is dominant with accompanying kaolinite and mixed-layered clays.

\section{Micrograin Size Analysis}

Three main micrograin size (microfacies) were distinguished in Site 391 sediments (Figure 6). 
Type I: Samples 391A-1-6, 50-42 cm; 391A-3-1, 136-138 $\mathrm{cm}$; and 391A-21-1, 120-122 cm include Pleistocene finely mottled or laminated calcareous silty clay and one sample of Cretaceous homogeneous mudstone.

Type IV: Samples 391A-1-5, 53-55 cm; 391A-3-2, 40-42 $\mathrm{cm}$; 391A-3-5, 10-12 cm; 391A-3-6, 126-128 cm; and $391 \mathrm{C}-4-1,145-147 \mathrm{~cm}$ include Pleistocene graded calcareous foraminifer silt, Miocene homogeneous calcareous silt, and layered Cretaceous sandy silt.

Type III: Samples 391B-1-4, 98-100 cm; 391-4-1, 113-115 $\mathrm{cm}$, and $391 \mathrm{~A}-4-4,45-47 \mathrm{~cm}$ consist of Pleistocene homogeneous foraminifer sand and Miocene mottled or clastic marly chalk.

\section{Discussion}

Pleistocene sedimentation at Site 391 in the Blake-Bahama Basin seems to have been characterized by contour currents that deposited terrigenous sediments and also induced solution of calcareous organisms - principally planktonic foraminifers. Sample 391A-1-5, 53-55 cm, was probably deposited from a turbidity current. The clay mineral assemblages are characterized by the abundance of primary rocks minerals which suggests low chemical weathering. This feature also commonly occurs in Pleistocene sediments.

The interpretation of depositional environment of the Miocene sediments is not easy because of their "allochthonous" character. There are significant differences between Samples 391A-3-2, 40-42 cm and 3-5, 10-12 cm, which exhibit both a typical turbidity current facies with displaced benthic foraminifers (found in the coarse fraction) and typical sorting, and Samples 391A-4-1, 113-115 cm and $4-4,45-47 \mathrm{~cm}$ where both turbidity and geostrophic current effects are suggested, and where foraminifers showed traces of solution. Moreover, the very high content of smectite in Core 4 suggests that Miocene deposits were reworked.

The analytical results suggest turbidity currents (Sample $391 \mathrm{C}-4-1,145-147 \mathrm{~cm}$ ), and/or gentle oceanic circulation (Sample 391A-21-1, 120-122 cm) prevailed during the Cretaceous at the time when the carbonaceous sediments were deposited. This suspected influence by turbidity currents is consistent with results of organic geochemical analyses. Deroo, et al. (this volume) showed that the sediments contain a large amount of plant detritus and humic matter of continental origin. The oceanographic conditions prevailing during deposition of the black shales are not clear. Stagnant conditions in a euxinic environment or very large contributions of carbonaceous detritis (related to expansion of the phanerogamic plants on land?) could have contributed to the formation of the black shales. Results from study of the sediments, although very incomplete, appear to support the second hypothesis.

\section{Site 392}

Site 392 is on the southeastern lip of the Blake Nose in 2607 meters of water. Two holes, 392 and 392A, were drilled here and the total length of the cored section is 295.0 meters. Four lithological units were defined. Unit 1 ( $90 \mathrm{~m}$ thick) is soft sediment comprising various colored Campanian to Barremian nannofossil oozes and marly nannofossil oozes. A layer of manganiferous sediment caps this unit. Lithological units 2, 3, and 4 are hard, massive, Barremian or older, limestones, with three distinct facies:
Unit 2 is a fenestral limestone at 90 meters to 213 meters sub-bottom depth. Unit 3 is an oolitic limestone cored between 213 and 242 meters. Unit 4 is a cavernous skelmoldic limestone.

No Santonian to Cenomanian sediments were found; a hiatus between upper Campanian to upper Albian (time gap $=30 \mathrm{~m} . \mathrm{y}$. .) occurs as at Site 390 .

We studied 17 samples from Campanian to Barremian sediments of unit 1. In the upper part of this unit (Hole 392A, Core 1) the color of the structureless nannofossil ooze varies from pale yellow ( 5 Y $7 / 3)$, to pinkish white ( 5 YR $8 / 2)$, and very pale brown $(10 \mathrm{YR} 8 / 4,8 / 3)$. In the middle part (392A, Core 2 and Core 3, Section 1 and part of Section 2) it is dark gray (10YR 4/1), mottled marly nannofossil ooze with some limestone fragments. The lower part (392A, Core 3, part of Section 2, and Core 4) is very pale brown (10YR 8/3) and light yellowish brown (10YR 7/4) nannofossil oozes in which brown limestone are interbedded. A red oolitic breccia in the lower part of Core 4 marks the boundary with unit 2 .

\section{Sedimentological Results}

The results of the sedimentologic determinations are given in Table 6.

Calcium carbonate contents range from 31 per cent to 91 per cent (average 61\%). Coarse fraction $(\phi>63 \mu \mathrm{m})$ percentages range between 0.3 per cent and 7.3 per cent, except for two samples, 392A-1-1, 106-108 cm and $392 \mathrm{~A}-3-3,142-143 \mathrm{~cm}$, where they are 44.5 per cent and 21.0 per cent, respectively.

The coarse fraction $(\phi>125 \mu \mathrm{m})$ is characterized by abundant planktonic foraminifer tests which usually form between 27 and 97 per cent of the fraction. The lowermost two samples, taken from Core 4, Section 1 , comprise only 1.6 and 4.1 per cent of planktonic foraminifer tests respectively. Terrigenous fragments, mostly quartz grains, are present in Cores 2 and 3 which contain Albian sediments and in Core 4, Section 1, which contains Barremian sediments. Mica is common $(8 \%-12 \%)$ in Core 2 and 3, Section 1 . The authigenic fraction, from Core 2 , is composed of glauconite, manganiferous coatings, and tracings of pyrite (middle to upper Albian). Muddy aggregates, sometimes red colored, are abundant in Cores 3 and 4. Siliceous organisms or fragments (sponge spicules) are only present in bottom samples where their percentages range between 0.3 per cent and 0.8 per cent.

\section{Mineralogy}

X-ray analysis made on silt fractions $(63 \mu \mathrm{m}>\phi>20$ $\mu \mathrm{m})$ show levels characterized by the alternative dominance of calcite (392A-1-2, 139-141 cm, upper Campanian; 392A-2-1, 30-32 cm, middle-upper Albian; 392A-3-2, $101-103 \mathrm{~cm}, 133-135 \mathrm{~cm}, 392 \mathrm{~A}-3-3,4-6 \mathrm{~cm}, 142-143 \mathrm{~cm}$, upper Aptian) and quartz with traces of feldspars (392A-2-1, $81-83 \mathrm{~cm}$ to 3-1, 92-94 cm (Albian)). Dolomite occurs with calcite in the upper Aptian samples (392A-3-2, 101-103 cm to $3-3,144-146 \mathrm{~cm}$ ).

$\mathrm{X}$-ray analyses of the clay fractions show strong mineralogical differences. Barremian sediments are characterized by smectite predominance $(65 \%-85 \%)$ on illite (15\%-25\%), mixed-layered clays (traces-10\%), kaolinite and probably attapulgite (traces). Upper Aptian and lower to middle Albian sediments show two assemblages, the first 
TABLE 5

Summary of Coarse Fraction Components, Grain Size, and Mineralogic Results, Site 391

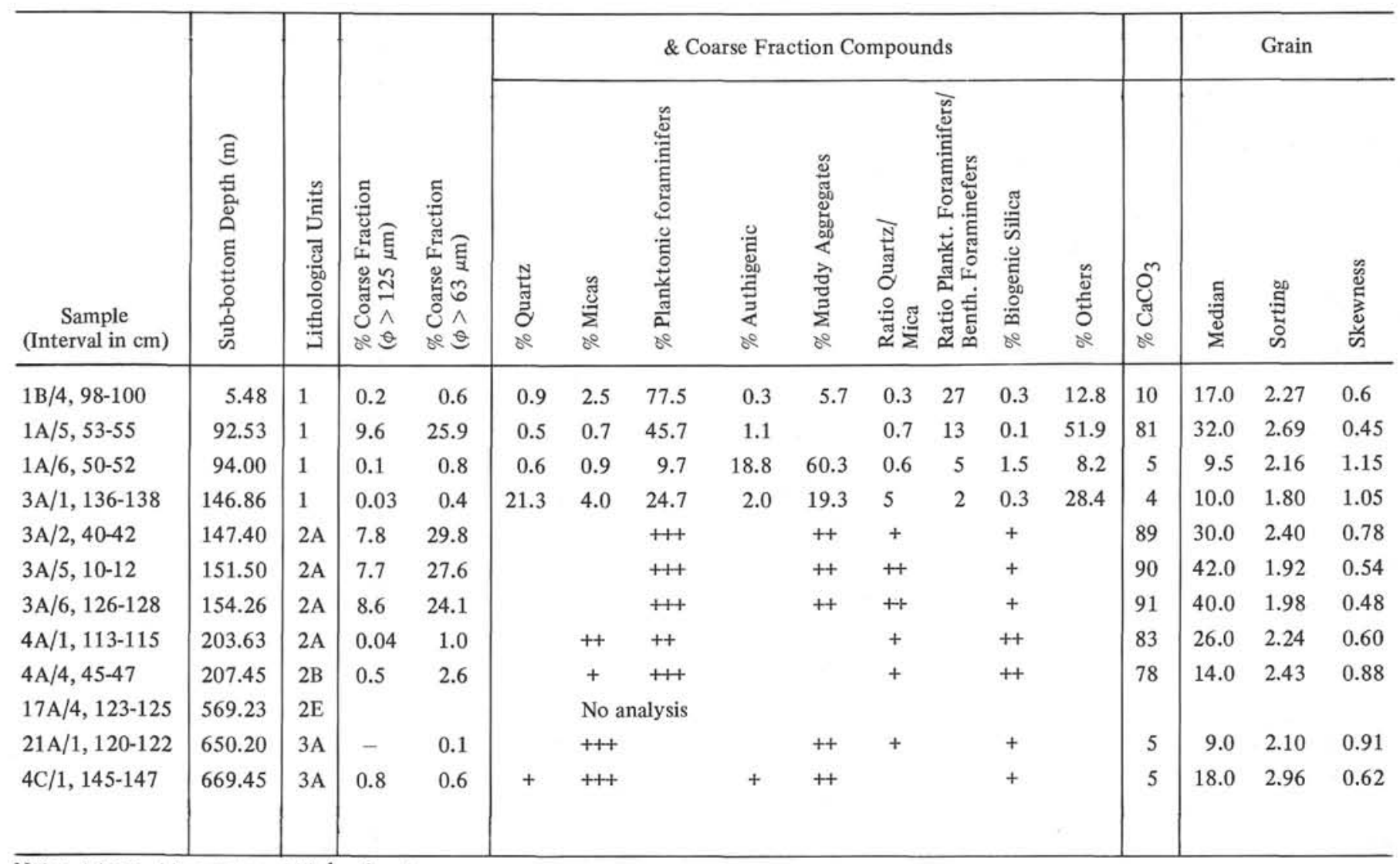

Note: + trace, ++ common, +++ dominant.

(Core 3, Section 3, and Core 3, Section 2, 133-135 cm) has illite $(45 \%)$ and mixed-layered clays and smectite $(20 \%)$, the second (Core 3, Section 2, 101-103 cm, Core 3, Section 1) has a higher smectite content $(60 \%-95 \%)$. This last assemblage persists in middle to upper Albian sediments (Core 2). Upper Campanian sediments are marked by an increase in kaolinite, illite, and mixed-layered clays.

\section{Micrograin Size Analyses}

Samples are grouped in three micrograin size groups (Figure 7).

The first group (type I) includes Samples 392A-1-2, 31-33 $\mathrm{cm}$; 392A-2-1, 30-32 cm; 392A-2-1, 81-83 cm; 392A-2-1, $102-104 \mathrm{~cm} ; 392 \mathrm{~A}-3-3,62-64 \mathrm{~cm} ; 392 \mathrm{~A}-3-1,82-84 \mathrm{~cm}$; 392A-3-2, 101-103 cm; 392A-3-2, 133-135 cm; 392A-3-3, $4-6 \mathrm{~cm} ; 392 \mathrm{~A}-3-3,144-146 \mathrm{~cm}$; and $392 \mathrm{~A}-4-1,128-130 \mathrm{~cm}$. Sediments belonging to this facies are either nannofossil oozes or marly nannofossil oozes and have no definite structure. They range from upper Campanian to Barremian. The second group (type III) includes Samples 392A-2-2, 124-126 cm; 392A-3-1, 92-94 cm; and 392A-4-1, 116-119 $\mathrm{cm}$. These are Albian or Barremian, structureless, marly nannofossil oozes. The third group (type VI) includes Samples 392A-3-3, 142-143 cm. The first two samples are and $392 \mathrm{~A}-3-3,142-143 \mathrm{~cm}$. The first two samples are structureless upper Campanian foraminifer nannofossil ooze, the last one is structureless upper Aptian ooze.

\section{Discussion}

In Core 392A-3-2 (upper Aptian), at $70 \mathrm{~cm}$, a $20-\mathrm{cm}$ indurated horizon (pale yellow 5 Y $8 / 3$ and yellow 5 Y $7 / 6$ limestone fragments) separates a very pale brown $(5 Y$ 8/3) nannofossil ooze from an overlying dark gray (10YR 4/1) mottled marly nannofossil ooze. The lowermost upper Aptian and Barremian sequence is characterized by abundant calcite, occasionally associated with dolomite in the silt fraction, and by the dominance of illite and presence of mixed-layered clays in the clayey assemblage. The micrograin size facies is mostly of type I which is probably characteristic of deposition by gentle contour currents.

The sediment content of the overlying Albian sequence is markedly different and consists of more abundant including mica flakes, terrigenous components, and the predominance of smectite and traces of attapulgite in the clay assemblages. On the basis of the micrograin size facies it was probably deposition either from turbidity currents (of low density type?) or from weak currents. This is consistent with the view that the sediments were deposited in deep water during that time. (See also Site 392 Report, this volume.)

A major hiatus in sedimentation occurs between the Albian nannofossil ooze and the upper Campanian foraminifer-nannofossil ooze. This gap could be caused by variations in hydrological processes (increasing current activity?) which could be related to the opening of the South 
TABLE 5 - Continued

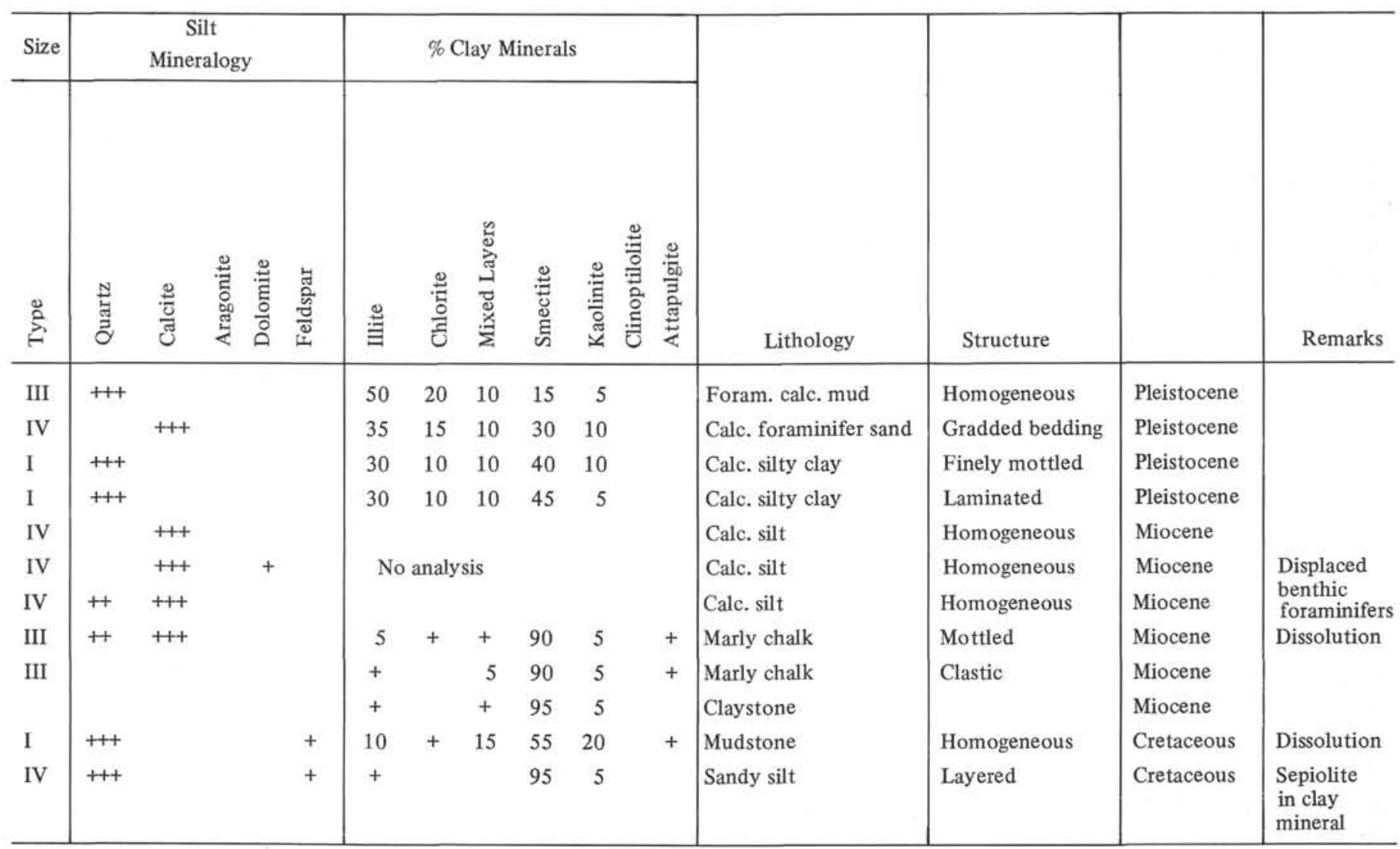

Atlantic Ocean believed to have taken place during Cenomanian time (Berggren and Hollister, 1974).

Upper Campanian deposits are characterized by high $\mathrm{CaCO}_{3}$ content, dominance of planktonic foraminifers in the coarse fraction, and increasing amounts of kaolinite and illite in the clay mineral fractions. This kind of deposit seems to be typical of a pelagic sedimentation regime, and is probably related to warmer climates than during Albian time.

\section{CONCLUSION}

To our knowledge, no general theory of the relationship between sedimentary processes acting in the deep sea and the resulting type of particle-size distribution exists at present. We suggest that the consideration of sorting, skewness, and median can afford a clue toward the understanding of sedimentary processes.

One of the limitations to our approach, with regard to processes of sediment transport and sedimentation, is that we did not consider the dimension of the particle of equivalent settling velocity. It has previously been shown (Berthois and Auffret, 1965) that settling velocities of quartz and mica of the same volume diameter in the range of 10 to $40 \mu \mathrm{m}$ differ by a factor of between 3 and 7. Particle-size distributions derived from settling velocities would certainly give different mean-size parameters but it is not known whether or not this would alter, in a reverse sense, the sorting and skewness tendencies.

Certainly relative changes in oceanic productivity or in the level of carbonate compensation depth (CCD), as well as changes in terrigenous sources could alter the textural characteristics. These influences must not be disregarded, but clearly in a regime of active circulation, fluctuations in current intensity would also be recorded in the sediment by variations of the textural characteristics.

Deposits recovered during Leg 44 consist of upper Kimmeridgian or Tithonian to Pleistocene/Holocene sediments and rocks. Our investigations were devoted to soft Barremian-upper Aptian to Pleistocene/Holocene sediments. Although the stratigraphic sections encountered in the different holes are far from complete, the combination of all the data allows us to examine the sedimentologic evolution of this part of the western North Atlantic continental margin.

Our results suggest that during the Cretaceous this portion of the western North Atlantic was characterized by low-energy current activity. The Albian to Upper Cretaceous carbonaceous clay ('black shales') recovered at Site 391 was deposited either by low intensity circulation or occasionally by turbidity currents. During this time smectite was dominant in the clay fraction. These observations suggest that the "black shales" were not deposited in an euxinic environment; they consist of terrigenous detrital or carbonaceous components and are similar to Pleistocene sediments deposited in deltaic environment (Thiede et al., 1974).

Results obtained from the examination of lower Albian to lower Maestrichtian nannofossil ooze or foraminiferal nannofossil ooze and marly nannofossil ooze samples at Sites 390 and 392 suggest that these were deposited from low 


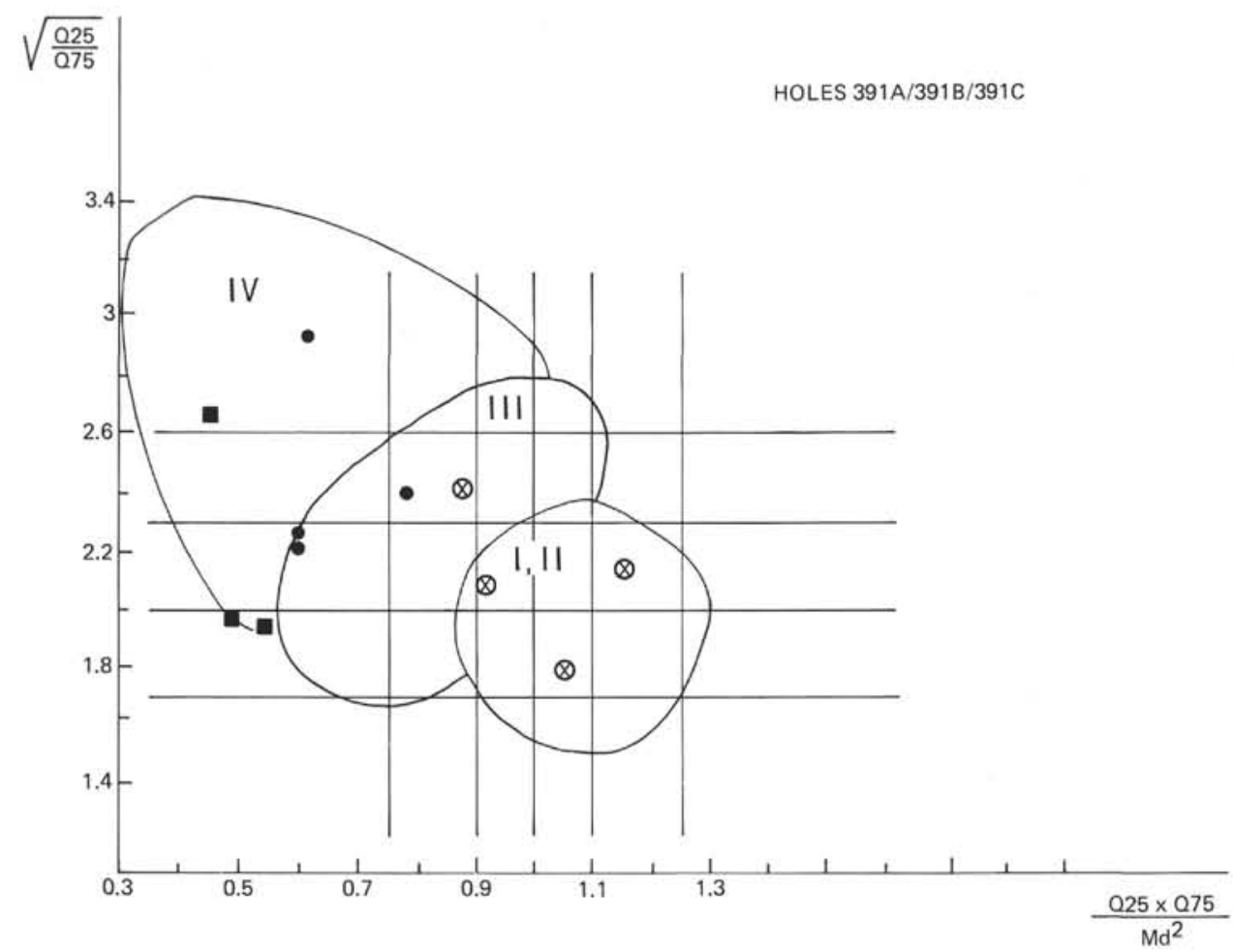

Figure 6. Micrograin size type (microfacies) of Site 391 samples.

intensity current or occasionally from turbidity currents. The clay assemblages in those sediments are variable and suggest climatic fluctuations during that time. A transition to more intense weathering of a tropical type followed the temperate to warm and wet Aptian and Albian climate. However, these variations could partly result from sorting processes in relation to continental tectonic activity or from sediment transport (changing sources, distal or proximal facies of turbidite, contourite) the generally warm (tropical) water, determined on the basis of carbonate isotope studies (Létolle, et al., this volume), as well as the latitudinal stability of northern America during this period (Berggren and Hollister, 1974), suggests that sedimentary processes may have been responsible for the observed variations of the clay mineral assemblages.

An important hiatus ( 30 m.y.) occurs on the Blake Plateau at Sites 390 and 392 between middle Albian and upper Campanian sediments. Evidence of truncation and erosion of Cenomanian to Santonian sediments is suggested on the seismic profiles of the Blake Nose (see Site 390 and 392 Reports, this volume). This hiatus could be related to non-deposition or erosion at the edge of the Blake Nose.

We suggest that the second hiatus ( $7 \mathrm{~m} . \mathrm{y}$.) occurring on the Blake Nose at Site 390 between upper Maestrichtian and lower Paleocene is related to an intensification of the bottom current activity.

Microfacies of samples from the Paleocene to middle Eocene from Site 390 suggest that active currents were responsible for the particle-size distribution of type II. Occasional occurrence of grain size type $\mathrm{V}$ suggests tranquil sedimentation regime in late Paleocene and early Eocene. The current activity appears to be the main oceanographic event that occurred in the region. At Site 390 the strong circulation was accompanied by the deposition of silica-rich deposits. The clay assemblages are characterized by large quantities of smectite accompanied by clinoptilolite (zeolite). The scarcity of typical terrigenous components suggests that they have a volcanic source. The presence of some volcanic glass shards in the coarse fractions and an increase in manganese concentrations at Hole 390A,Core 4 to Core 2 (Renard and Létolle, this volume) further support this possibility. Nevertheless, a contribution from smectite-rich soils or sediments must also be considered. The geographic origin of the smectite and the agents responsible for its transport (bottom and/or surface currents) are not known. The early Tertiary, however, was a time of widespread volcanic activity, in the central Atlantic (Antilles, Caribbean)(MacGillavry, 1970) as well as in the northern Atlantic (Montadert, Roberts, et al., in press) and the Norwegian Sea. At this time the surface current regime was characterized by the Gulf Stream system and the bottom currents were characterized by a two-system regime (Antarctic and Arctic Bottom Water). The final agent responsible for the deposition, as seen from the particle size distribution was probably active bottom circulation.

Because we did not recover upper Eocene, Oligocene, and lower Miocene sediments, we will not discuss the oceanographic evolution and microfacies during that time. Results concerning this period appear in Volume 11 of the DSDP Initial Reports series.

At the foot of the lower continental rise north of the Blake-Bahama Outer Ridge, middle and upper Miocene muds have been recovered (Site 388). They were probably deposited below the carbonate compensation depth (CCD) and are rich in clay minerals; smectite is particularly abundant. Particle-size distribution of types II and III 
suggests deposition from active contour currents and/or turbidity currents. As in the Eocene, the origin of smectite and the agent responsible for its transport are not clear. The source could have been regional and deposition influenced by reworking of Eocene outcrops by current and/or turbidity currents. A marine source, related to volcanism, could have existed in the North Atlantic, Arctic Ocean, or in Caribbean-Antilles areas. From our data, we cannot choose between these two possibilities. A southern pedogenetic origin for smectite deposited in the North Atlantic during the Pleistocene has been proposed by several authors (Rotschy and Chamley, 1971; Pastouret et al., 1975). At Site 391 in the Blake-Bahama Basin, Miocene calcareous sediments consisting of massive gravity flows originated from the Blake Plateau (see Site 391 Report, this volume). These sediments alternate with in place claystone and mudstone that are much too indurated to be submitted to the analytical procedures. As in the Miocene samples of Site 388 the displaced sediments are rich in smectite.

Pliocene deposits were not recovered during Leg 44 . Observations pertaining to the sedimentary processes prevailing during the Pliocene are given in Volume 11 of the DSDP Initial Reports series (Lancelot et al., 1972).

Few samples of Pleistocene sediments were studied. The analytical results of these samples show that during that time both influences of gentle contour current and turbidity current prevailed. Clay assemblages from this time are very different from those of the earlier episodes. They are directly related to the climatic conditions that favor deposition of primary rock minerals little altered by weathering processes. Because so few samples were studied and particularly because of the total lack of Pliocene sediments, we have not discussed the consequences of the closing of the Panama Isthmus that very probably occurred during the Pliocene (3.5-4 m.y., Berggren and Hollister, 1974).

\section{ACKNOWLEDGMENTS}

We acknowledge the assistance of all the members of the Leg 44 shipboard scientific party (Chief Scientists W. E. Benson from the National Science Foundation, Washington, and R. E. Sheridan from the University of Delaware, Newark, Delaware). The participation of one of the authors (LP) and the laboratory work were supported by the National Science Foundation and the Centre National pour l'Exploitation des Océans. Suzanne Marques, Ghislaine Giroud d'Argoud, and René Kerbrat were in charge of laboratory procedures. The manuscript was typed by Nicole Giullo-Uchard. The clay mineral studies were supported by CNEXO Grant 76/5320.

\section{REFERENCES}

Berggren, W. A. and Hollister, C. D., 1974. Paleogeography, paleobiogeography and the history of circulation in the Atlantic region. In Hay, W. W. (Ed.), Studies in paleooceanography: S.E.P.M., Spec. Publ. 20, p. 126-186.

Berthois, L. and Auffret, G. A., 1965. Application d'un compteur électronique à la mesure des vitesses de chute des particules fines: Acad. Sci. Paris, v. 261, p. 5165-5167.

Chamley, H., 1971. Recherches sur la sédimentation argileuse en Méditerranée. Thèse de doctorat d'Etat, Sciences Naturelles, Faculté des Sciences de Marseille.

Folk, R. L., 1968. Petrology of sedimentary rocks: Austin, Texas (Hemphill's Book Store).

Hollister, C. D., 1967. Sediment distribution and deep circulation in the western North Atlantic: Unpublished Ph.D. dissertation, Columbia University.

Lancelot, Y., Hathaway, J. C., and Hollister, C. D., 1972. Lithology of sediments from the western north Atlantic Leg 11 DSDP. In Hollister, C. D., Ewing, J. E., et al., Initial Reports of the Deep Sea Drilling Project, Volume II: Washington (U.S. Government Printing Office), p. 901-949.

MacGillavry, H. J., 1970. Geological history of the Caribbean: $K$. Nederl. Akad. Wetensch,, ser. B. no. 73, p. 64-96.

Montadert, L., Roberts, D. G., Auffret, G. A., Bock, W. D., Dupeuble, P. A., Hailwood, E. A., Harrison, W., Kagami, H., Lumsden, D. N., Müller, C., Schnitker, D., Thompson, R. W., Thompson, T. L., and Timofeev, P. P., in press. Passive margin drilling by Glomar Challenger in the Bay of Biscay and on the Rockall Plateau: Geotimes.

Passega, R., 1964. Grain-size representation of clastic deposition: Am. Assoc. Petrol. Geol. Bull., v. 41, p. 1952-1984.

Pastouret, L., Auffret, G. A., Hoffert, M., Melguen, M., Needham, H. D., and Latouche, C., 1975. Sedimentation sur la ride de Terre-Neuve: Earth Sci. v. 12, p. 1019-1035.

Rotschy, F. and Chamley, H., 1971. Comparaison des données des foraminifères planctoniques et des minéraux argileux dans une carotte nord-atlantique:Eclog. Geol.Helv., v. 64, p. 279-289.

Sarnthein, M., 1971. Oberflächensedimente im Persischen Golf und Golf von Oman II. Quantitative Komponenten-analyse der Grossfraktion: "Metero" Forsch.-Ergebn., v. 5, p. 1-113.

Thiede, J., 1974. Sediment coarse fractions from the western Indian Ocean and the Gulf of Aden (Deep Sea Drilling Project, Leg 24). In Fisher, R. L., Bunce, E. T., et al., Initial Reports of the Deep Sea Drilling Project, Volume 24: Washington (U.S. Government Printing Office), p. 651-765.

Thiede, J., Pastouret, L., and Melguen, M., 1974. Sédimentation profounde au large du delta du Niger (golfe de Guinée): C. R. Acad. Sci. Paris, v. 278, p. 987-990.

Wentworth, C. K., 1922. A scale of grade and class terms for clastic sediments: J. Geol., v. 30, p. 377-392. 
TABLE 6

Summary of Coarse Fraction Components, Grain Size, and Mineralogic Results, Site 392

\begin{tabular}{|c|c|c|c|c|c|c|c|c|c|c|c|c|c|c|c|c|c|}
\hline \multirow[b]{2}{*}{$\begin{array}{c}\text { Sample } \\
\text { (Interval in } \mathrm{cm} \text { ) }\end{array}$} & \multirow[b]{2}{*}{ 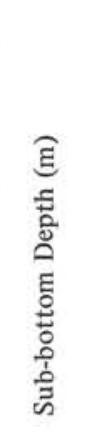 } & \multirow[b]{2}{*}{ 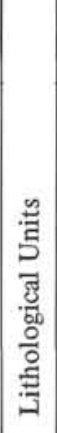 } & \multirow[b]{2}{*}{ 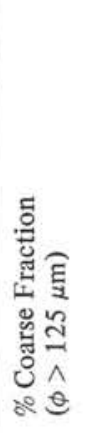 } & \multirow[b]{2}{*}{ 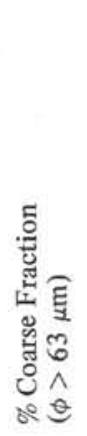 } & \multicolumn{9}{|c|}{$\%$ Coarse Fraction Components } & \multirow[b]{2}{*}{ 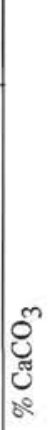 } & \multicolumn{3}{|c|}{ Grain } \\
\hline & & & & & 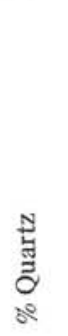 & $\sum_{0}^{\infty}$ & 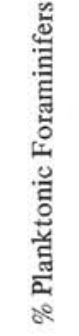 & 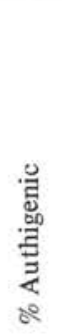 & 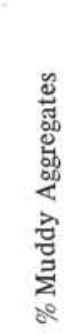 & 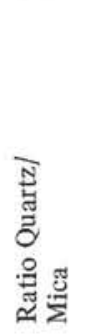 & 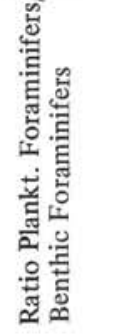 & 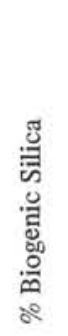 & $\begin{array}{l}\stackrel{2}{0} \\
\stackrel{5}{0} \\
02\end{array}$ & & 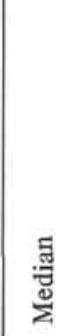 & 邑 & 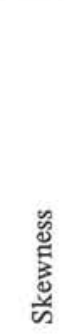 \\
\hline $1-1,106-108$ & 51.56 & 1 & 36.6 & 44.5 & & 0.3 & 96.2 & & & 0 & 192 & & 3.5 & 83 & 28 & 4.08 & 3.06 \\
\hline $1-2,31-33$ & 52.31 & 1 & 2.2 & 3.5 & & & 96.5 & & & & 482 & & 3.5 & 89 & 10.0 & 1.83 & 1.20 \\
\hline $1-2,139-141$ & 53.39 & 1 & 4.4 & 7.3 & & & 97.4 & & & & 243 & & 2.6 & 91 & 7.2 & 2.56 & 1.83 \\
\hline $2-1,30-32$ & 60.30 & 1 & 0.4 & 1.5 & & 0.8 & 82.7 & 0.5 & & 0 & 34 & & 16.0 & 50 & 9.6 & 2.29 & 0.91 \\
\hline $2-1,81-83$ & 60.81 & 1 & 0.1 & 1.5 & 0.3 & 5.6 & 70.6 & 0.8 & & 0.05 & 13 & & 22.7 & 31 & 9.8 & 2.09 & 0.96 \\
\hline $2-1,102-104$ & 61.02 & 1 & 0.2 & 2.5 & & 7.9 & 57.1 & 0.6 & & 0 & 10 & & 34.4 & 38 & 9.0 & 2.01 & 1.10 \\
\hline $2-2,124-126$ & 62.74 & 1 & 0.3 & 1.1 & & 3.6 & 73.5 & 0.2 & 0.9 & 0 & 15 & & 21.8 & 38 & 12.5 & 1.98 & 0.79 \\
\hline $3-1,62-64$ & 79.62 & 1 & 1.4 & 4.7 & 0.2 & 11.9 & 27.0 & & & 0.02 & 6 & & 60.9 & 45 & 9.4 & 2.45 & 1.09 \\
\hline $3-1,82-84$ & 79.82 & 1 & 1.1 & 2.6 & 0.1 & 7.8 & 34.8 & 0.3 & & 0.01 & 8 & 0.3 & 56.7 & 46 & 8.5 & 2.09 & 0.92 \\
\hline $3-1,92-94$ & 79.92 & 1 & 1.1 & 2.9 & & 8.0 & 56.2 & & & 0 & 17 & & 35.8 & 44 & 11.5 & 1.97 & 0.86 \\
\hline $3-2,101-103$ & 81.51 & 1 & 4.5 & 6.5 & & 2.1 & 70.2 & & & 0 & 10 & & 27.7 & 86 & 6.4 & 1.98 & 1.05 \\
\hline $3-2,133-135$ & 81.83 & 1 & 0.7 & 1.4 & & 0.6 & 71.3 & & & 0 & 36 & & 28.1 & 65 & 7.0 & 1.99 & 1.16 \\
\hline $3-3,4-6$ & 82.04 & 1 & 1.5 & 2.5 & & & 71.4 & & & & 16 & & 28.6 & 69 & 7.4 & 2.05 & 1.11 \\
\hline $3-3,142-143$ & 83.42 & 1 & 18.0 & 21.0 & & 0.5 & 48.3 & & 26.5 & 0 & 9 & & 24.7 & 88 & 11.0 & 2.89 & 1.59 \\
\hline $3-3,144-146$ & 83.44 & 1 & 2.0 & 4.4 & 0.1 & 0.6 & 72.0 & & & 0.17 & 13 & & 27.3 & 77 & 7.6 & 2.33 & 1.15 \\
\hline $4-1,116-119$ & 89.66 & 1 & 0.9 & 1.0 & 0.6 & 1.6 & 4.2 & & 13.2 & 0.38 & 0.3 & 0.3 & 80.1 & 49 & 13.0 & 2.04 & 0.89 \\
\hline $4-1,128-130$ & 89.78 & 1 & 0.1 & 0.3 & 4.0 & 4.8 & 1.6 & 0.2 & & 0.83 & 0.06 & 0.8 & 88.6 & 56 & 10.5 & 2.02 & 1.08 \\
\hline
\end{tabular}

Note: + traces, ++ common, +++ dominant. 
TABLE 6 - Continued

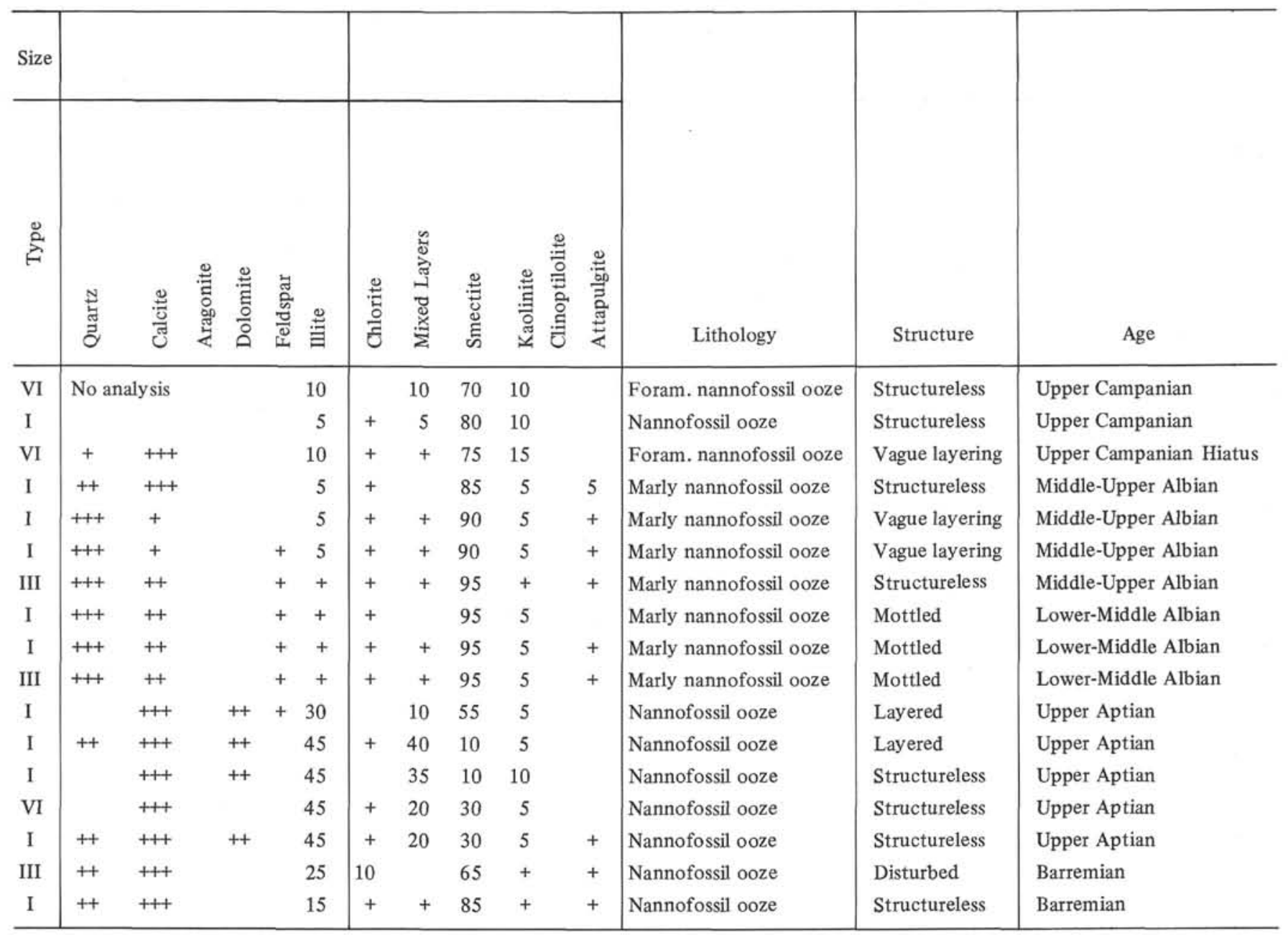




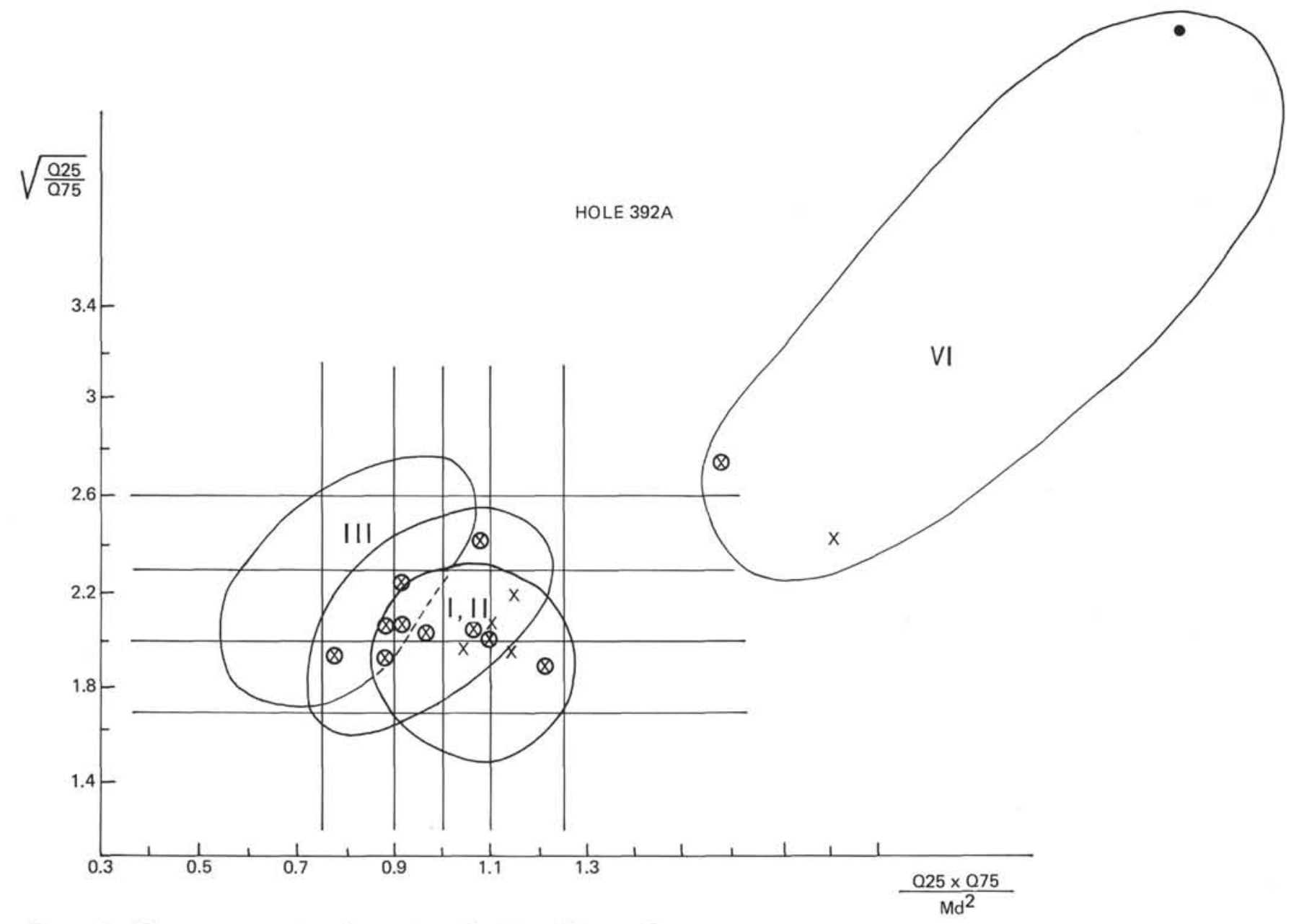

Figure 7. Micrograin size type (microfacies) of Site 392 samples. 



\section{PLATE 1}

Figure 1 Sample $388-2-3,120-122 \mathrm{~cm}$, Pleistocene. Microfacies I. Note the alternating beds of minerals and nannofossils and, except for the presence of coccoliths in the Pleistocene sediment, the similarity to Figure 8 "black shale" facies. $\times 2050$.

Figure 2 Sample $388-2-3,120-122 \mathrm{~cm}$ showing detail; $\times 5100$.

Figure 3 Sample $388-2-3,120-122 \mathrm{~cm}$. Weathered phyllite mineral; $\times 5100$.

Figure 4 Sample 390A-1-1, 120-122 cm, middle Eocene. Note the relatively well preserved calcareous nannofossils and the occurrence of phyllitic mineral; $\times 2000$.

Figure 5 Sample 390A-1-1, 120-122 cm; $\times 2000$.

Figure 6 Sample 390A-7-4, 120-122 cm, lower Eocene. Microfacies II. Siliceous and calcareous nannofossils are abundant. Note the good sorting and the poor preservation of detritus except for the smallest calcareous nannofossils $(0<5 \mu \mathrm{m}) ; \times 2000$.

Figure 7 Sample 390A-6-2, 10-12 cm, lower Eocene. Microfacies II. Calcareous nannofossils and debris are abundant. Siliceous sponge spicules are present; $\times 2080$. 


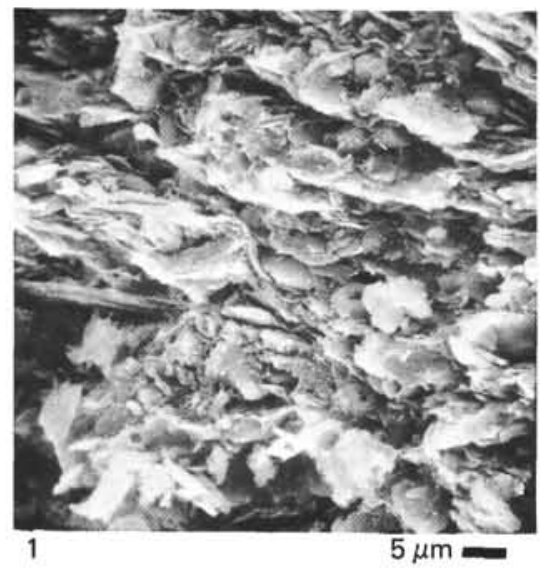

PLATE 1
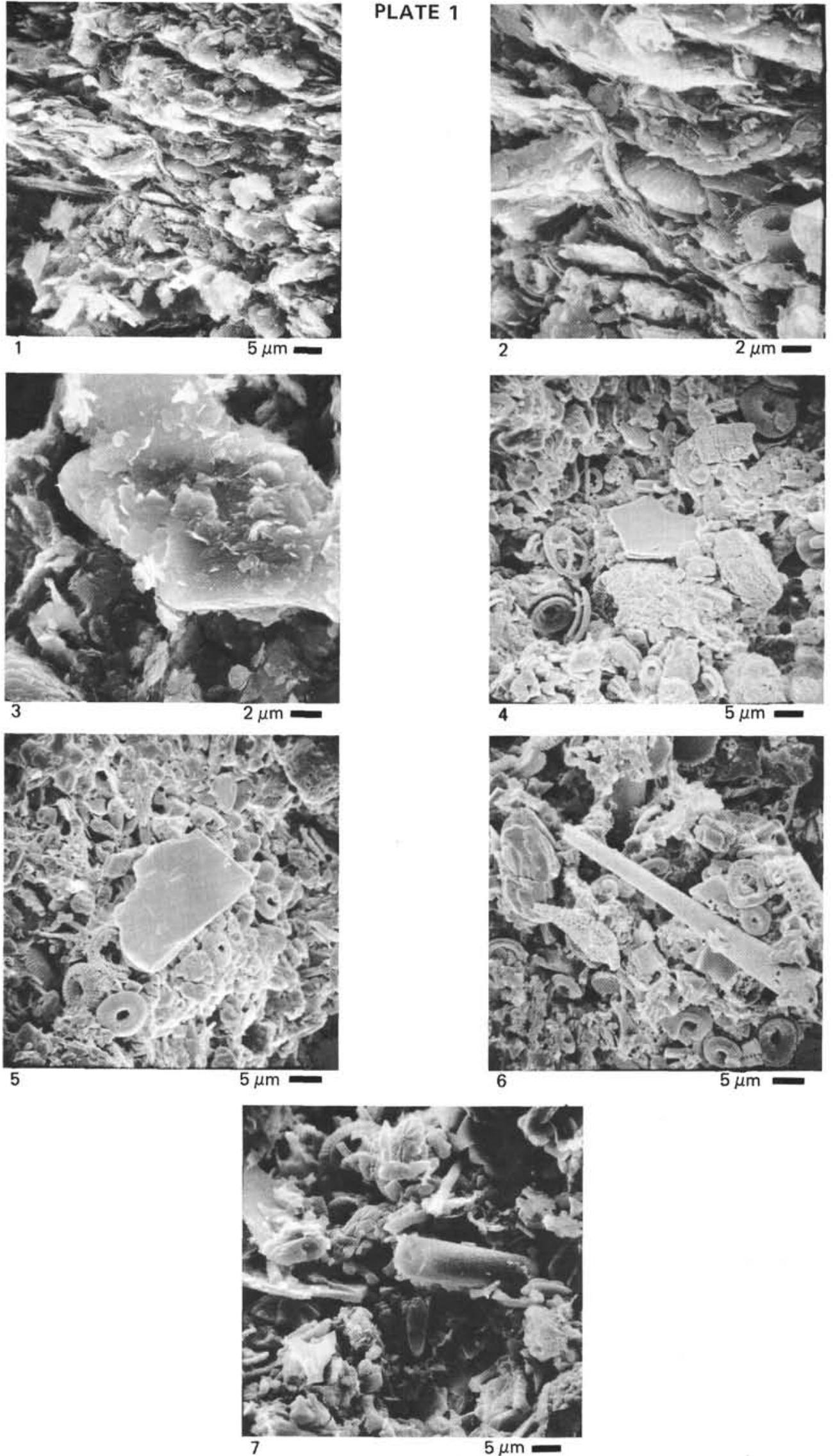


\section{PLATE 2}

Figure 1 Sample 391A-21-1, 120-122 cm. Cretaceous "black shales." Microfacies I. Photo is probably at right angle to bedding plan. Note similarity to Figure 1 structure; $\times 1000$.

Figure 2 Detail of Sample 391A-21-1, 120-122 cm. Note the presence of pore; $\times 1800$.

Figure 3 Sample 391C-4-1, 145-147 cm. Cretaceous "black shales." Microfacies I. Quartz (?); $\times 2100$.

Figure 4 Samples 391C-4-1, 145-147 cm. Note the smoothed edges of the euhedral mineral and occurrence of smaller particles on its surface (aggregates ?); $\times 2000$.

Figure 5 Sample 391C-4-1, 145-147 cm. Biogenic debris; $\times 960$.

Figure 6 Sample 390-5-2, 26-28 cm, upper Aptian. Microfacies III. In general particules are small $(\phi \leqslant 5 \mu \mathrm{m})$ and are isometric; they probably consist of nannofossil fragments. Note the lack of clayey matrix; $\times 2180$.

Figure 7 Sample 390-5-2, 26-28 cm. Detail of Figure $6 ; \times 5250$. 

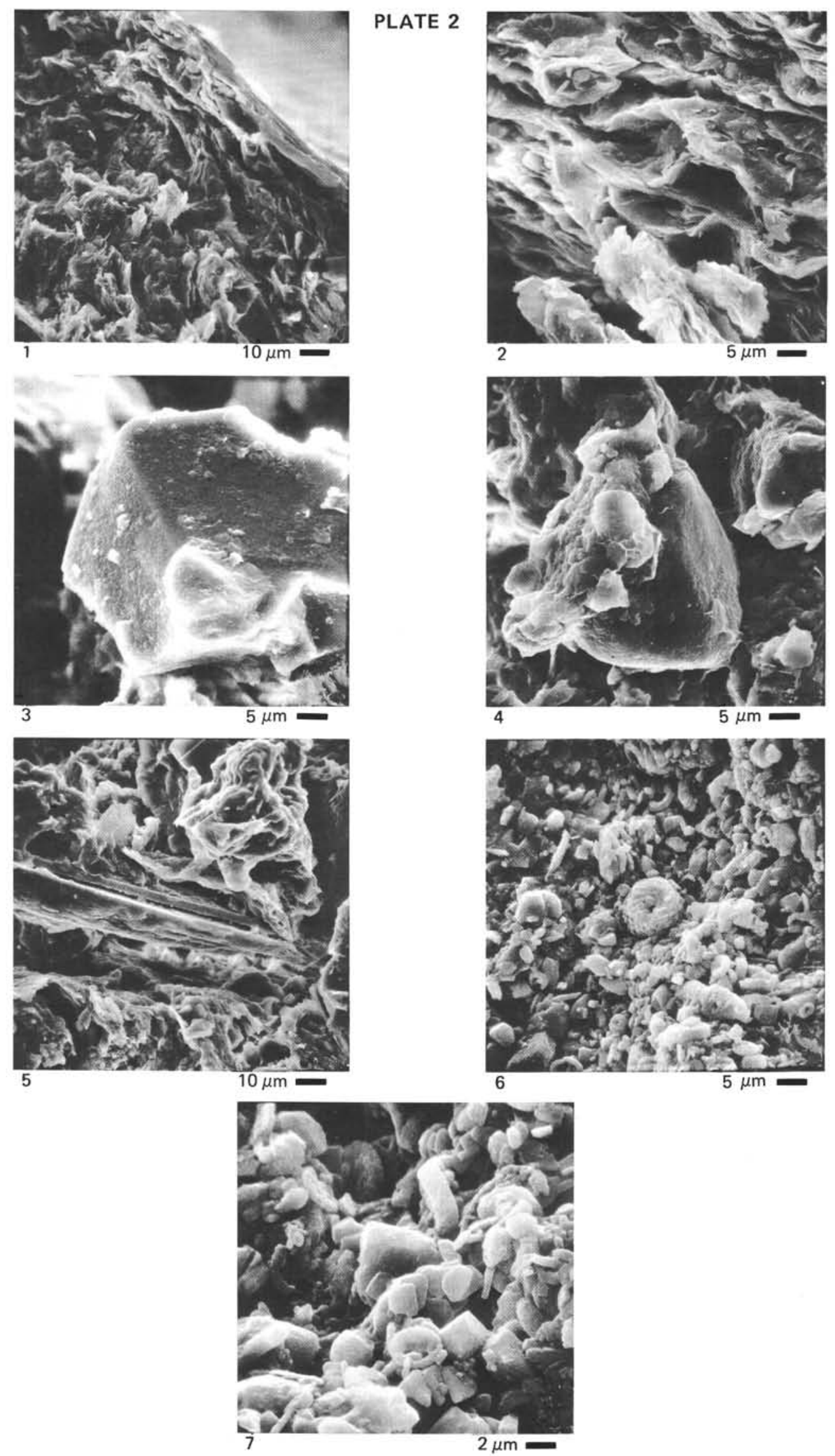